\title{
LEIBNIZ'S THEORIES OF CONTINGENCY
}

\author{
by Robert Merrihew Adams
}

\section{INTRODUCTION}

There is a familiar conception of Leibniz's views about the nature of necessity and contingency which portrays him as a sort of grandfather of possible worlds semantics for modal logic. According to this conception, Leibniz envisages an infinity of possible worlds, of which God (who exists necessarily) chooses and actualizes one (the best). Necessary truths are propositions that are true in all possible worlds. Contingent truths are propositions that are true in the actual world but false in at least one other possible world. What worlds are possible, what would happen in them, and how they are related to one another as similar or dissimilar, better or worse, do not change from one world to another; and therefore all truths about what is possible are necessary. (This Leibniz is, to be precise, a grandfather of possible worlds semantics for S5, the strongest of the usual systems of modal logic.) For this reason also the property of being the best possible world belongs necessarily to the world that has it. The root of all contingency is that it is not necessary but only contingent that God chooses to actualize the best. All and only those truths are contingent whose truth depends on God's free choice of the best.

We meet this Leibniz in Chapter III of Bertrand Russell's Critical Exposition of the Philosophy of Leibniz. An important part of Russell's interpretation is the famous exception he makes in Leibniz's principle that in every true proposition the concept of the predicate is contained in the concept of the subject. "The assertion of existence, alone among predicates, is synthetic," Russell says, "and therefore, in Leibniz's view, contingent." All other predicates are contained in the concepts of subjects that have them; but existence is not, except in the case of God. Therefore truths about what any possible individual or possible world is like, or would be like if it existed or were actual, are all necessary; but it is contingent which possible world is actual, and therefore which possible individuals exist.

Robert Adams is Professor of Philosophy at the University of California at Los Angeles. 
Russell gave up these views after reading Couturat. But according to E. M. Curley, "Recent discussions ... have tended in some measure to go back to Russell's original view (before Couturat) that, apart from the proposition that God exists, existential truths are not analytic." 2 I think that the tendency described by Curley does indeed exist, and is quite broadly favorable to the picture of Leibniz held by Russell before Couturat. But it seems to me to be leading us backward, not only in time, but also in our understanding of Leibniz. For the familiar Leibniz described above is in large part a creature of misunderstanding, though not exactly of fiction.

A variety of conceptions of the problem of contingency, and solutions to it, can be found in Leibniz's writings. There was development in his thought on it, and he held more than one solution at once. There are two main solutions, to be set out in sections 1.0-1.5 and 2.0-2.6, respectively, of the present paper. An accurate account of Leibniz's theories of contingency will therefore be rather complex. We will come toward the end of it, rather than at the beginning, to the question whether he regarded existence as a predicate contained in the concepts of things that exist.

\subsection{Leibniz's First Main Solution}

Leibniz tells us that even before he thought of the problem of contingency in terms of his analytic theory of truth, he had "found [himself] very close to the opinion of those who hold everything to be absolutely necessary," but "was pulled back from this precipice by considering those possible things which neither are nor will be nor have been" (FC 178/L 263). ${ }^{3}$ Just how close he was to the cliff, we shall see in section 1.1; and in sections 1.2-1.5 we shall consider the way in which he says he was rescued from it.

\subsection{The Letter to Wedderkopf}

In May 1671 Leibniz wrote a letter to Magnus Wedderkopf, a legal scholar in Kiel, about "the necessity of events" (A II,i,117f./L 146f.). ${ }^{4} \mathrm{He}$ begins by arguing that everything that happens is determined by God's decree, and admitting that this is a "hard" conclusion. He then begins to trace the cause of Pilate's damnation, from his lack of faith to his failure to pay attention, to his failure to understand the utility of paying attention, to a lack of causes of such understanding.

For it is necessary to analyze everything into some reason, and not to stop until we arrive at a first reason-or else it must be admitted that something can exist without a sufficient reason for its existence, and this admission destroys the demonstration of the existence of God and of many Philosophical theorems. What then is the ultimate reason of the divine will? The divine intellect. For God wills those things that $\mathrm{He}$ understands to be best and most harmonious, and selects them, as it were, from an infinite number of all possibles.

Leibniz goes on to state that the ultimate reason of things is found in the essences, possibilities, or ideas of things, which "coincide with God Himself," 
are understood by $\mathrm{Him}$, and have no reason outside themselves. Leibniz draws a strongly necessitarian conclusion:

Since God is the most perfect mind, however, it is impossible for Him not to be affected by the most perfect harmony, and thus to be necessitated to the best by the very ideality of things. ... Hence it follows that whatever has happened, is happening, or will happen is best and therefore necessary, but ... with a necessity that takes nothing away from freedom because it takes nothing from the will and the use of reason.

Three points deserve comment here.

(1) Leibniz has already slipped over the edge of the precipice in this letter. $\mathrm{He}$ states flatly and without qualification that everything that ever happens is necessary. This is his simplest solution of the problem of contingency. If there is no contingency, there is no need to account for it or explain its nature.

But Leibniz did not remain content with this position. On his own copy of the letter to Wedderkopf he later wrote, "I have since corrected this; for it is one thing for sins to be infallibly going to happen, and another thing for them to be going to happen necessarily." He continued to ascribe necessity to all things, but only with some qualification. "What is actual is in some way necessary" (Gr 536; emphasis mine). Even in free actions there is allowed to be "hypothetical" and "moral" necessity, but not "absolute" or "metaphysical" necessity (G VI,37/Preface to the Theodicy).

(2) Leibniz was a compatibilist, maintaining to the end of his life (to Clarke, V,3) that every event is determined but some acts are nonetheless free. According to the formula of his maturity, freedom consists in intelligence (understanding the object of deliberation), spontaneity (insofar as the source of the action is within the agent), and contingency (which excludes absolute, logical, or metaphysical necessity, but not hypothetical or moral necessity) (T 288-290, 302). In the letter to Wedderkopf, however, we meet a more extreme compatibilism, which does not make contingency a necessary condition of freedom. In this early work voluntariness and intelligence seem to suffice for freedom: necessity "takes nothing away from freedom because it takes nothing from the will and the use of reason." The later addition of contingency as a condition of freedom is surely related to the change in Leibniz's willingness to admit without qualification the necessity of all events, but the latter development in his thought comes sooner than the former. In a work of 1673, in which he argues vigorously against the claim that sins are (unqualifiedly) necessary (Conf $54 \mathrm{ff}$.), he still says, "To preserve the privilege of free will, it is enough that we have been so placed at a fork in the road of life, that we do only what we will, and will only what we believe to be good" (Conf 82). Later, however, Leibniz distinguished a sense in which freedom is opposed to necessity and a sense in which it is opposed only to compulsion (B 121); and in several texts from the years $1681-1685$ ( $\mathrm{Gr} 299,308,229$; cf. G VII, 108-111) and later (Gr 421, G III,58f.) he ascribes both kinds of freedom to human agents. 
(3) In the letter to Wedderkopf the argument for the necessity of all events is not based (at least not explicitly) on the analytic theory of truth, but rather on the nature of God and the principle of sufficient reason. This latter, more theological argument against contingency is by far the one most often addressed by Leibniz in his writings; and we shall be concerned with it in most of the present essay.

The letter to Wedderkopf is an exceptional text. It is hard to regard as merely tentative a view which Leibniz communicated to an eminent person with whom he was by no means intimate. But he may not have held the extreme necessitarian position for any length of time. It seems not to have been held in a fragment on free will written just a few months before or after the letter (A VI,i,540f.). ${ }^{5}$

\subsection{Things Possible in Their Own Nature}

The necessitarian position was soon replaced by a theory which Leibniz repeated incessantly, publicly and privately, to the end of his career, and which must be regarded as his principal (and most confident) solution to the problem of contingency. The basic idea of this solution is very clearly stated in a paper on freedom written about 1681 .

\footnotetext{
But we must say that God wills the best by His own nature. Therefore He wills necessarily, you will say. I shall say with St. Augustine that that necessity is happy. But surely it follows from this that things exist necessarily. Why? Because a contradiction is implied by the non-existence of that which God wills to exist? I deny that that proposition is absolutely true. Otherwise those things which God does not will would not be possible. For they remain possible, even if they are not chosen by God. It is possible indeed that even that should exist which God does not will to exist, because it would be able to exist of its own nature if God willed that it exist. But God cannot will that it exist. I agree; yet it remains possible in its own nature, even if it is not possible in respect to the divine will. For we have defined possible in its own nature as that which does not imply a contradiction in itself 6 even if its coexistence with God can be said in some way to imply a contradiction....

Therefore I say: that is possible, of which there is some essence or reality, or which can be distinctly understood. . . . If God had decreed that no real line must be found which should be incommensurable with other real lines (I call real a line that actually bounds some body), it would not therefore follow that the existence of an incommensurable line implies a contradiction, even if God, from the principle of perfection, could not fail to ordain in this way. (Gr 289f.)
}

On this view the actual world, and things that exist in it, are not necessary but contingent, because other worlds are possible in which those things would not exist. And the possibility of those other worlds does not depend on the possibility of God's choosing them. It is enough, for the contingency of the actual world, if the other possible worlds are "possible in their own nature" or "do not imply a contradiction in themselves," considered apart from God's choice.

Leibniz still takes this position in the Theodicy. He reports that Abelard agreed "that it can well be said that that man [who in fact will be damned] can 
be saved, in respect to the possibility of human nature, which is capable of salvation, but that it cannot be said that God can save him, in respect to God Himself, because it is impossible for God to do that which He ought not to do." And he comments that Abelard therefore need not have held, as he did, that "God cannot do anything but that which He does." For "the others ... do not mean anything else when they say that God can save that man, and that He can do that which He does not do" (T 171). The possibility of the alternatives among which God chooses is internal to them; and this internal possibility of the alternatives is enough to make God's choice free.

\footnotetext{
In a word, when one speaks of the possibility of a thing it is not a question of the causes that can bring about or prevent its actual existence: otherwise one would change the nature of the terms and render useless the distinction between the possible and the actual.... That is why, when one asks if a thing is possible or necessary, and brings in the consideration of what God wills or chooses, one alters the issue. For God chooses among the possibles, and for that very reason $\mathrm{He}$ chooses freely, and is not compelled; there would be neither choice nor freedom if there were but one course possible. (T 235; cf. T 44, 45, 228, 230-232, $234,367)$
}

The first problem about this theory is to understand what is meant by "possible in its own nature." If a certain world is inferior and so cannot be chosen by God, is that not by virtue of its own nature? Why, then, should we not say that it is impossible in its own nature? Here we must think of the nature or concept of a possible world as built up by stages. We start with the notion of a group of monads, of the different degrees of distinctness with which each perceives the others, and of the geometrical configurations and motions that are expressed by their perceptions and have thus a phenomenal reality. If there are spirits among the created monads of the world in question, we include their thoughts, actions, speeches, and cultural productions. Thus is built up what we may call the basic concept of a possible world. It is to include everything that happens in that world, but not everything that is true about its relation to God's will. By analogy with the complete concept of an individual, we can also speak of the complete concept of a possible world, which is to be fuller than the basic concept and contain everything that is true about the possible world, including whether it is the best, or nearly the best, or far from the best, of all possible worlds, and whether God therefore chooses or rejects it. ${ }^{7}$ We may take it to be Leibniz's position that a world is possible in its own nature if its basic concept contains no internal contradiction, and nothing that is incompatible with its actuality so long as certain determinants of God's choice are kept out of the picture; its complete concept may contain God's rejecting it, but that does not keep it from being possible in its own nature.

Interesting questions arise about just what is to be included in a world's basic concept. (1) Are any concepts of other possible worlds included? It might seem natural to exclude them, since we are trying to capture the idea of 
a possibility that is internal to one possible world. And by excluding them we can be certain of not including enough information to imply God's rejection of the world to which the basic concept belongs. On the other hand, the solution of the problem of contingency does not strictly require the exclusion of this information if the right information about God is excluded.

(2) Are any facts about God included in basic concepts of worlds? Leibniz refers to the world as "the Aggregate of finite things" (G VII,302/L 486), ${ }^{8}$ which presumably excludes God. On the other hand, he speaks of the possible things that are the objects of God's choice as containing in their concepts certain decisions of God, considered as possible, so that God chooses among certain possible actions of $\mathrm{His}$ own, as well as among possible creatures (C 23f.; G II,49-51/L-A 55-57; cf. G I,360). This causes no problem, provided that the divine decisions that are included in the objects of God's choice are non-comparative decisions concerned only with the laws or order of the world to which they belong. What is important for Leibniz's treatment of contingency is that the basic concepts of possible worlds do not contain God's choice among possible worlds. If in addition they do not include the fact that God is perfectly good, they can contain concepts of other possible worlds, without damage to the theory of contingency.

\subsection{Hypothetical Necessity}

Even if a satisfactory explanation can be given of what it is for a world (or more generally, a state of affairs or thing) to be possible in its own nature, there remains an important objection to Leibniz's use of this notion in accounting for contingency. His claim is that the actuality of this world is contingent because other worlds remain possible in their own natures even if they are not possible in relation to God's will. But in presenting this theory of contingency, Leibniz at least sometimes seems to admit that it is necessary that God chooses this world (Gr 289f., Conf 64f.). And if it is necessary that God chooses this world, and it follows necessarily from that that this world is actual, must not the actuality of this world be necessary and not contingent? As Curley puts it,

It is an uncontroversial truth of modal logic that if $p$ is necessary and $p$ entails $q$, then $q$ is necessary. So if it is (absolutely) necessary that God choose the best, and if the existence of the best world is (hypothetically) necessary in relation to his choice, then it is (absolutely) necessary that the best world exist. 9

Leibniz makes much use of the term "hypothetically necessary," which Curley rightly brings in here. Leibniz says repeatedly that contingent truths are hypothetically but not absolutely necessary (e.g., in $\$ 13$ of the Discourse on Metaphysics). "Hypothetical necessity" is normally, as he recognized (G III, 400/W 481), a synonym of "necessity of the consequence." So he seems to be using the traditional distinction between necessity of the consequence and necessity of the consequent: "If $p$ then necessarily $q$ "10 can mean either 
that "If $p$ then $q$ " is necessary (necessity of the consequence), or that if " $p$ " is true then " $q$ " is necessary (necessity of the consequent). But then necessity of the consequence (hypothetical necessity) combined with necessity of the antecedent implies necessity of the consequent. If " $p$ " and "If $p$ then $q$ " are both necessary, then " $q$ " is necessary.

Leibniz raised this very objection against himself in his "first Theodicy," written in dialogue form in 1673 as The Philosopher's Confession, and given to Arnauld and others."

God's existence is necessary. From it follow the sins that are contained in [this actual] series of things. What follows from the necessary is necessary. Therefore the sins are necessary. (Conf 64)

\section{The answer that Leibniz first wrote was:}

I reply that it is false that whatever follows from what is necessary is necessary. From truths, to be sure, nothing follows that is not true. Yet since a particular [conclusion] can follow from purely universal [premises], as in [the syllogistic figures] Darapti and Felapton, why not something contingent from something necessary? (Conf 64) ${ }^{12}$

Thus baldly stated, Leibniz's answer seems simply to ignore the modal axiom appealed to by Curley. Leibniz acknowledged the axiom, however, at least by 1675 , when he wrote, "Whatever is incompatible with something necessary is impossible." He therefore distinguished two types of necessity and impossibility. "The concept of the impossible is twofold: that which has no essence; and that which has no existence or which neither was nor is nor will be, and which is incompatible with God or with existence or with the reason which makes things to be rather than not." 13 Leibniz accordingly corrected his answer in the manuscript of The Philosopher's Confession (probably sometime between 1673 and 1677), to incorporate such a distinction:

I reply that it is false that whatever follows from what is necessary through itself, is necessary through itself. From truths, to be sure, nothing follows that is not true. Yet since a particular [conclusion] can follow from purely universal [premises], as in [the syllogistic figures] Darapti and Felapton, why may not something that is contingent, or necessary on the hypothesis of something else, follow from something that is necessary through itself? $(\text { Conf } 64)^{14}$

He also added,

In this place we call necessary only that which is necessary through itself-that is, which has the reason of its existence and truth within itself. Such are the Geometrical truths, and of existing things only GOD. The others, which follow from the supposition of this series of things - that is, from the harmony of things-or from the Existence of GOD, are contingent through themselves and only hypothetically necessary. . . (Conf 66$)^{15}$

Here it is clear that in spite of the traditional terminology of hypothetical necessity, the absolute or per se necessity that Leibniz denies in affirming contingency is something more than the traditional necessity of the conse- 
quent. In his conception of hypothetical necessity the absolute necessity or contingency of the antecedent is no more important than the externality of the antecedent to the consequent. What follows necessarily from what is necessary through itself is certainly necessary by necessity of the consequent, in the traditional sense. It is not necessary through itself, however, but only hypothetically necessary, and contingent, in Leibniz's sense, if the antecedent from which it follows is external to it, and not contained in its own nature. The phrase Leibniz uses here, "necessary ex alterius hypothesi" ("necessary on the hypothesis of something else") expresses his meaning better than the more usual "necessary ex hypothesi."

This conception of hypothetical necessity is expressed only slightly less clearly in another early passage. On November 27, 1677, Leibniz recorded his side of a conversation with Bishop Nicholas Steno (Niels Stensen), who read The Philosopher's Confession and commented on it. ${ }^{16}$ In this memorandum Leibniz says that "there is an absolute necessity when a thing cannot even be understood, but implies a contradiction in terms," and "there is a hypothetical necessity when a thing's being some other way can indeed be understood through itself, but it is necessarily this way, non-essentially [per accidens], on account of other things outside itself already presupposed" (Gr 270f.).

In his later writings Leibniz is usually less explicit about his interpretation of hypothetical necessity, and indeed does not remain consistent on the point. The conception we have found in his early work occurs in a paper dating from 1692 or later (according to Schepers; Grua dated in 1677):

All things therefore have a reason, either in themselves and from their terms [in se et ex terminis], as things that are necessary through themselves [per se]; or from elsewhere, as things that are free and contingent or, so to speak, non-essentially or hypothetically [per accidens sive ex hypothesi] necessary. (Gr 273; cf. Gr 297f. [1681], T 53 [1710])

The evidence that Leibniz's adherence to this position was not consistent and unwavering has to do with the question whether effects that are contingent in the sense of being only hypothetically necessary must have contingent causes. There are a paper from about 1683 (Gr $310 \mathrm{f}$.) and a reading note from about 1695 ( $\mathrm{Gr} 353$ ) that hint at, but do not unambiguously imply, an affirmative answer to this question. And writing to Arnauld in 1686, Leibniz says that "the possibilities of individuals or of contingent truths contain in their concept the possibility of their causes, namely of the free decisions of God" (G II, 51/L-A 56). Similarly, Leibniz seems to think that the possibility of an effect requires the possibility, though not the actuality, of some cause of it, when he says, in a letter of 1714 to Louis Bourguet, "Generally speaking, in order for a being to be possible, it suffices that its efficient cause be possible; I except the supreme efficient cause, which must exist in fact" (G III, 572/L 661). ${ }^{17}$ In neither of these passages is it explicit that the possibility of the 
cause is required for a thing to be possible in itself, nor how far up the explanatory chain the possibility of the cause must extend. Perhaps it is enough if particular divine decrees or decisions to establish such and such laws of nature are possible in themselves, or included in consistent basic concepts of worlds; perhaps they need not be possible in relation to God's perfect goodness. But it is natural to read these passages as incompatible with the view that contingency is definable in terms of the internal possibility of basic (but incomplete) concepts of alternative worlds.

On the other hand, Leibniz does say in the Theodicy that considerations about what God chooses, and in general about the causes of a thing, are not relevant to the question of the thing's possibility ( $T$ 235, quoted in section 1.2 above). And it would not be plausible to interpret Leibniz there as meaning only that the actuality of the causes is irrelevant, while tacitly assuming that the possibility of the causes is relevant; for he is explicitly attacking Abelard, whom he reads ( $\mathrm{T}$ 171) as arguing, not merely from the non-actuality, but from the alleged impossibility of God's having chosen otherwise than He did.

Perhaps Leibniz in his later work found it easier to vacillate on the question whether a contingent effect can follow by hypothetical necessity from an absolutely necessary cause, because the question had lost some of its importance for him. For, as we shall see, he had come to believe that God's choice of this world to actualize is contingent, and therefore that contingent existences do have a contingent cause in God. Nevertheless the idea that it is enough for contingency that there are a plurality of alternatives for God's choice that are possible in themselves is more clearly and emphatically presented in the Theodicy than any other well articulated solution to the problem of contingency.

\subsection{The Reality of Choice}

We may be tempted to object that the conception of the contingent as that which has some alternative that is possible in itself (if not in relation to God) does not really show how there can be any contingency in the Leibnizian universe, nor how God's choice among possible worlds can be free. For what is contingent in this Leibnizian sense may still be necessary by necessity of the consequent-that is, absolutely necessary-in the traditional (and twentieth century) sense. And God's choice of this world to actualize may be necessitated by $\mathrm{His}$ nature as perfectly good, even if other worlds remain possible in themselves. If this is all that Leibniz has to offer in defense of contingency, his system may be thought as necessitarian as Spinoza's.

Most of what is said in this objection is right, in a way; but it overlooks the nature of Leibniz's interest in free will and contingency, and his stated view of the difference between his determinism and Spinoza's. His interest in contingency is rooted in his interest in divine and human free will-with respect to which he is, after all, a compatibilist. We must let him define for himself what kind of compatibilist he is. At one time, as we have seen, he regarded unqualified necessity as compatible with freedom. Later his principal reason for 
insisting on some sort of contingency in connection with free action seems to have been to insure the reality of choice-to insure that what happens is really influenced by final causes and judgments of value.

This is the point that Leibniz most often insists on in distinguishing his views about necessity from Spinoza's. Spinoza held that there are no final causes in nature, that God does not act for an end, and that things are called good or bad with regard only to how they affect us, being quite indifferent to God (Ethics, I, Appendix). He said that actual intellect and will must be referred to God-as-an-effect (natura naturata) and not to God-as-a-cause (natura naturans) (Ethics, I, prop. 31), and denied that a divine intellect or will could resemble ours in anything more than name alone (Ethics, I, prop. 17, schol.). Indeed there is no room in Spinoza's system for God to choose, for there is nothing to be excluded by His choice. By the necessity of the divine nature, since it is infinite in Spinoza's sense, absolutely everything possible must be actual (Ethics, I, prop. 16).

On all of these points Leibniz disagreed with Spinoza. Even on the most extremely necessitarian interpretation of his system, God's choice has a real and important role to play. For even if God's choice of this world is necessary, other worlds are possible in their own nature, and are not excluded without God's choice but only through (the necessity of) His choosing this one. God's choice is an indispensable link in the chain of explanation for the actuality of this world. "The nature of things, taken without intelligence and without choice, has nothing sufficiently determining" (T 350). The comparative value of the different worlds also has a crucial explanatory role, in which Leibniz employs a notion of final cause. ${ }^{18}$

Leibniz emphasizes this disagreement in his discussions of Spinoza, early and late. In the period 1676-1678, near the time of Spinoza's death, Leibniz commented, "But it is not at all to be thought that all things follow from God's nature without any intervention of the will" (G I,124; cf. Gr 279), and "Even if it is true that not everything happens for the sake of men, it still does not follow that [God] acts without will or understanding of the good" (G I,150/L 205). In the Theodicy he wrote,

Spinoza ... appears to have explicitly taught a blind necessity, having denied to the author of things understanding and will, and imagining that good and perfection relate only to us and not to Him. It is true that Spinoza's opinion on this subject is somewhat obscure.... Nevertheless, as far as one can understand him, he acknowledges no goodness in God, properly speaking, and he teaches that all things exist by the necessity of the Divine nature, without God making any choice. We will not amuse ourselves here in refuting an opinion so bad, and indeed so inexplicable. Our own is founded on the nature of the possiblesthat is to say, of the things that do not imply any contradiction. (T 173; cf. T 174, 371-374)

If we will allow Leibniz to disagree with Spinoza in his own way, rather than in some way that we might impose on him, this should be enough to show that his determinism is not properly called Spinozistic. 


\subsection{Moral Necessity}

When Leibniz says that he opposes a "brute" or "blind" necessity (T 174, 349), he means (sometimes with explicit reference to Spinoza) a necessity that denies to God intelligence and choice (T 371-372). Similarly, in the Theodicy ${ }^{19}$ he admits a "moral" but not a "metaphysical" necessity of God's choosing the best. Leibniz usually gives little or no explanation of this distinction; and one might be tempted to take it as a promissory note for a less strongly necessitarian theory which he was unable to provide in detail. But in fact "morally necessary" had a precise meaning. The morally necessary is what one morally ought to do. In his early jurisprudential writings (1671-1678) Leibniz enunciated a system of moral modalities (a very rudimentary deontic logic) in terms of what is possible, impossible, necessary, or contingent (i.e., omissible or not necessary) "to be done by a good man" (A VI,i,465ff.). "I call morally impossible that which it is not possible to do without committing a sin" (A IV,i,471). "Obligation ... is a moral necessity - that is, a necessity imposed on him who wants to keep the name of 'a good man'" (Gr 608). Similarly, "duty is whatever is necessary in the perfectly just" (C 517). Accordingly, when Leibniz says that God's choice of the best is morally necessary, we must take him to mean that it is necessary that if God did not choose the best, $\mathrm{He}$ would not be perfectly good. It is noteworthy that Clarke, his contemporary, did take this to be Leibniz's meaning. Clarke's examples of moral necessity are "that a good Being, continuing to be Good, cannot do Evil; or a wise Being, continuing to be Wise, cannot act unwisely; or a veracious Person, continuing to be veracious, cannot tell a Lie" (G VII,423). (Clarke also thought this a "figurative" and philosophically uninteresting sense of "necessity.")

It is in keeping with this conception that the Theodicy speaks of being "necessitated morally by wisdom" (T 237), identifies moral necessity with "the choice of the wise, worthy of his wisdom" (Preliminary Discourse, §2), and says that "it is a moral necessity that the wisest is obliged to choose the best" (T 230). And in some of his discussions of moral necessity Leibniz's concern for the reality of choice comes together pretty explicitly with his idea of the contingent as that which receives necessity only from outside itself and has alternatives that are possible in themselves. He distinguishes between "metaphysical necessity, which leaves no place for any choice, presenting only one possible object, and moral necessity, which obliges the wisest to choose the best" (T 367), and says,

\footnotetext{
But that sort of necessity which does not destroy the possibility of the contrary has that name only by analogy. It becomes effective, not by the essence of things alone, but by that which is outside them and above them, namely by the will of God. This necessity is called moral, because with the wise, what is necessary and what ought to be are equivalent things. (Abridgment, VIII [G VI,386])
} 


\subsection{Leibniz's Second Main Solution}

We have now explored the set of ideas that constitute the innermost and surest bastion of Leibniz's defenses against the denial of contingency. Even if everything actual is necessarily actualized by God, on account of His goodness, the things that God chooses are not necessary through themselves, but only on the hypothesis of something external to them, and they have alternatives that are possible in themselves. They are therefore in a certain sense contingent, and only hypothetically necessary. Leibniz finds contingency in this sense worth defending, because it preserves the reality of God's choice, distinguishing the "moral" necessity that he ascribes to God's action from the "brute" or "blind" necessity that he thinks belongs to it in Spinoza's system. Leibniz adhered to these views from 1673 to the end of his life.

But we have yet to examine the outer walls of his castle of contingency. In the end Leibniz denied, not only that this world, which in fact is actual, is necessary through itself, but also that it is necessarily actualized by God. In several papers from the 1680 s we see him struggling to justify this denial and fit it into his philosophy. But by 1690 he had made much progress in understanding the problem, and had attained a solution that seems to have satisfied him fairly well.

\subsection{The Contingency of Which World Is Best}

According to Leibniz, this world, rather than any other possible world, is actual because God chooses to actualize whatever is best, and this is the best of all possible worlds. Therefore, if it is contingent that this world is actual, it must either be contingent that God chooses whatever is best, or else contingent that this is the best. Which is it that is contingent? Leibniz explicitly raised this question in several papers written between 1689 and 1706; he tended to favor the answer that it is contingent that this world is the best.

In one note from about 1695 he raises the question without answering it:

The formal cause [of the knowability of future contingents] is the coherence of terms, or the fact that the predicate inheres in the subject, even if the cause why it inheres depends on two things, the universal bestness and God's decision to choose the best. Or is God's general decision necessary. ${ }^{20}$ Or is it not that "This is the best" is true, but not necessary; it is true but not demonstrable a priori. Is it therefore contingent? ( $\mathrm{Gr} 351$ )

Although the question is not answered here, Leibniz's inclination is clear.

It is explicit in other texts, including the important paper "On Contingency," from 1689 or 1690 , the earliest work known to me in which Leibniz defined the alternatives: 21

We must see whether if we suppose that this proposition is necessary: the proposition which has the greater reason for existing exists, it follows that the proposition which has the greater reason for existing is necessary. But the inference is rightly rejected. For if the definition of a necessary proposition is, that its truth can be demonstrated with geometrical rigor, then it can indeed happen that this proposition can be demonstrated: every truth, 
and only a truth, has the greater reason, or this one: God always acts most wisely. But it will not therefore be possible to demonstrate this proposition: contingent proposition $A$ has the greater reason, or contingent proposition $A$ is conformed to the divine wisdom. And therefore also it does not follow that contingent proposition A is necessary. And therefore even if it were conceded that it is necessary that God chooses the best, or that the best is necessary, still it does not follow that that which is chosen is necessary, since no demonstration that it is the best is given. ( $\mathrm{Gr} 305 \mathrm{f}$.)

Here Leibniz is rather careful not to assert that it is necessary that God chooses the best. But he does commit himself to the view that it is not necessary that this (which God has chosen) is the best, although it is in fact the best. Of the two ways in which the necessity of that which God has chosen could be denied, Leibniz is readier here to deny the necessity of "This is the best" than the necessity of "God chooses the best."

His stance is the same in a note written in the early 1690s:

Or. does this follow: "This proposition is necessary: God does the best. Therefore that which God does is necessary"? The inference is not valid. For the conclusion follows the weaker part. But it is not demonstrable that a certain thing is the best, nor, therefore, [can it be demonstrated] what must be done. Or shall we rather say that this proposition too, "God does the best," is not necessary but only certain? The previous opinion appears to be best, since this proposition: $\mathrm{A}$ is the best, is certain, but is not necessary since it cannot be demonstrated. (Gr 336)

We do not have to deny the necessity of "God does the best," since that which is the best is not necessarily the best.

In another text, the latest and most important of the series, Leibniz begins by stating again that "This is the best" is not necessary even if "That which is the best is chosen" is necessary. He says that he does not know whether God's not choosing the best implies a contradiction. But he asserts flatly that "This is the best," though true, "is not demonstrable by a demonstration that shows that the contrary implies a contradiction." Then he seems to change his mind, however, and shifts to a less cautious position on the necessity of God's choosing the best:

It is the same argument: God wills necessarily the work that is most worthy of His wisdom.
I say that He wills it, but not necessarily, because although this work is the most worthy,
that is not a necessary truth. ${ }^{22}$ It is true that this proposition: God wills the work that is
most worthy of Him, is necessary. But it is not true that He wills it necessarily. For this
proposition: This work is the most worthy, is not a necessary truth; it is indemonstrable,
contingent, a truth of fact. (Gr 493)

The argument here turns on an ambiguity of "necessarily." Leibniz saw it as an ambiguity of scope. He accepts the "necessarily" as "applied to the copula" (that is, to the whole proposition), but not as applied to "what is contained in the copula" (that is, as internal to the predicate). He will affirm that "God is necessarily the one who wills the best. But not the one who necessarily wills the best" (Gr 494). It is misleading, however, for Leibniz to make an issue of 
which verb "necessarily" modifies. The crucial point in the ambiguity is whether the necessity applies de re to the object that God in fact wills. This point could be brought out by distinguishing wide from narrow scope of the definite description operator in "God necessarily wills the work that is most worthy of His wisdom." If it has wide scope, the necessity applies de re to the work, and the sense of the proposition is, "The work that is most worthy of God's wisdom is such that it is necessary that God wills it"-which Leibniz denies. But if the definite description operator has narrow scope, the sense is rather, "It is necessary that God wills whatever work is most worthy of His wisdom"-which Leibniz here accepts. Of course it would be anachronistic to expect Leibniz to have made the point in that way.

The date of this text deserves comment. It cannot possibly have been written before 1706, because it is a note made in reading the third volume of Bayle's Réponses aux questions d'un provincial, which was published at the end of the previous year. ${ }^{23}$ This refutes Rescher's suggestion that it was only "until the year 1686, when his mature philosophy took form" that Leibniz preferred denying the necessity of "This is the best" to denying the necessity of "God chooses the best." ${ }^{24}$

It should also be noted that the proposition, "God wills necessarily the work that is most worthy of His wisdom," which is quoted from Bayle, is discussed again (with the same reference to Bayle) in the Theodicy, where it is denied ( $T$ 237). Leibniz does not make there the distinctions that he had made in the note from 1706, but only appeals to the difference between metaphysical and moral necessity. What he is denying in the Theodicy, however, should probably be understood in the light of the earlier note.

\subsection{Necessity, Demonstrability, and Infinite Analysis}

The thesis that the property of being the best of all possible worlds belongs only contingently to the world that has it has seemed so evidently false to some recent philosophers that they have been unwilling to regard it as a part of Leibniz's mature philosophy. "That this world is the best possible world is presumably a necessary fact," according to Curley; ${ }^{25}$ and Rescher says, "it is difficult to see how what is best could avoid being determined with necessitation when the substances are conceived sub ratione possibilitatis. ${ }^{26}$ That this world is the best does not depend on which world exists, or is actual, or chosen by God. Leibniz insists that the values of possible things are completely independent of God's will. ${ }^{27}$ The bestness of this world is rather the ground of its being chosen by God and hence actual and existent.

Nevertheless, Leibniz did in several of his later writings assert that the bestness of that which is best is contingent, as we have seen. And I do not know of any text from the mature period of his philosophy in which he asserts or implies the opposite. How can he have thought what he appears to have thought? The explanation is to be sought in the idea, which occurs in all of 
the crucial passages, that it cannot be demonstrated what is best. Leibniz brings in here, implicitly, his very formal ideal of demonstration by analysis in a finite number of steps. For of all his solutions to the theological version of the problem of contingency, that which proceeds by denying the necessity of facts about which things are best is the most clearly connected with his conception of contingency in terms of infinite analysis.

This conception is indeed rather fully stated in the earliest of the papers in which we have found Leibniz saying that it is contingent what is the best.

\begin{abstract}
And here ${ }^{28}$ is uncovered the inner distinction between necessary and contingent truths, which no one will easily understand unless he has some tincture of Mathematics-namely, that in necessary propositions one arrives, by an analysis continued to some point, at an identical equation (and this very thing is to demonstrate a truth in geometrical rigor); but in contingent propositions the analysis proceeds to infinity by reasons of reasons, so that indeed one never has a full demonstration, although there is always, underneath, a reason for the truth, even if ${ }^{29}$ it is perfectly understood only by God, who alone goes through an infinite series in one act of the mind. ( $\mathrm{Gr} 303)$
\end{abstract}

This is Leibniz's solution to the version of the problem of contingency that has fascinated his twentieth century readers, the version that asks, "if the concept of having the predicate at a given time inheres in the concept of the subject, how can the subject then lack the predicate without contradiction and $^{30}$ impossibility, and without loss of its concept?" (FC 179/L 264). The solution is that a predicate can be contained in the concept of a subject without this containment being provable by analysis in a finite number of steps. Leibniz will say that in such a case the subject's lacking the predicate does not "imply a contradiction," and that its having the predicate cannot be "demonstrated" and is contingent (FC 181/L 264; similarly at C 17/SG 346f.; cf. C 376f., 387/P 66, 76f.).

An example may help us to understand how such cases may arise. It may be that there is a property, $\phi$, such that for every natural number $n$, it can be proved that $n$ has $\phi$, but the universal generalization that every natural number has $\phi$ cannot be proved except by proving first that 7 has $\phi$, then that 4 has $\phi$, and so on until every natural number has been accounted for-a task that can never be completed. In this case it is a purely mathematical truth that every natural number has $\phi$, but it cannot be demonstrated. And it is a purely mathematical falsehood that some natural number lacks $\phi$, but no contradiction can be derived from it in a finite number of steps. Tarski decided to say that a system of which these conditions hold, but in which "Some natural number lacks $\phi$ " can be proved, is consistent, but not $\omega$-consistent. ${ }^{31} \mathrm{He}$ thus reserved the use of "consistent" and "inconsistent," without qualification, to express proof-theoretical notions rather than notions of mathematical possibility and mathematical falsity. Similarly, Leibniz reserves "implies a contradiction" to express a proof-theoretical notion rather than the notion of conceptual falsity or being false purely by 
virtue of the relations of concepts. He thinks, of course, that the latter notion is expressed simply by "false."

It is not difficult to see how it would follow, from this conception of contingency, that it is contingent which possible world is the best. For one would presumably have to consider infinitely many aspects of a world in order to assign a value to it as a whole. And then one would have to compare infinitely many worlds in order to determine which is best. It could not be determined by any finite analysis; hence it is contingent. Several commentators have explained Leibniz's reasoning along these lines, ${ }^{32}$ and Leibniz himself did so. In a paper on "Necessary and Contingent Truths" (Couturat's title), which may contain the earliest surviving statement of his infinite analysis conception of contingency, he points out that the universe has infinitely many aspects, and adds,

Indeed, even if one could know the whole series of the universe, one still could not give the reason for it, unless one had set up a comparison of it with all the other possible [series]. From this it is clear why no demonstration of any contingent proposition can be found, no matter how far the analysis of concepts is continued. (C 19/SG 349 [dated 1678 by Schepers]; cf. Gr 343 [from the early 1690s])

There remain difficult questions, never resolved by Leibniz or his commentators, about just how analysis is supposed to work in the relevant cases. Analysis, for Leibniz and the seventeenth century, was a method of proof beginning with the conclusion to be proved and working back to the axioms from which it follows - though in an infinite analysis the axioms are never reached. The method that begins with the axioms was called synthesis. ${ }^{33}$ In conformity with this distinction, Leibniz described finite and infinite analyses as proceeding from the proposition to be proved, by substituting definitions, or parts of definitions, for its terms (FC 181f./L 264f.). But the process of determining which is the best of all possible worlds by comparing the values of all the worlds seems likely to be a synthesis, rather than an analysis, in this sense. Indeed Leibniz gives us no idea how one would even begin an analysis, finite or infinite, to determine which world is the best possible, although it is clear that he thought the infinite number of worlds to be compared is one ground of the contingency of God's choice of this world. Perhaps something like the following form of analysis is intended. Let "W*" be a proper name of the world that happens to be actual. An analysis of "W* = the best of all possible worlds" will require the replacement of one or both sides of the equation by an analysans. But in order to reduce the equation to identities by such replacement we would need on the right-hand side an analysans including a statement of the complete (or at least the basic) concepts of all possible worlds; and that is not finitely statable.

Another difficulty is that while it does seem that it could not be proved in a finite number of steps that a certain world is the best possible, there might perhaps be a finite proof that a certain world, or any world of a certain sort, is 
not the best possible. Leibniz himself seems to have thought it could be demonstrated that no world in which God damns the innocent is the best.

The damnation of the innocent is indeed possible in itself, or something that does not imply a contradiction; but it is not possible for God.... For we do not need to examine the whole harmony of things in order to know whether God is going to damn someone innocent eternally. (Gr 300)

Here Leibniz seems to be confronted with a truth, "No one innocent will be damned eternally," which satisfies one of his criteria for contingency (its contrary is possible in itself), but not the other (it would not require an infinite analysis to prove it). Leibniz does not tell us how to resolve this conflict; indeed I doubt that he realized its existence.

We may also be tempted to object that the infinite analysis conception of contingency represents contingency as illusory, or at best merely relative to our intellectual incapacity (as Spinoza had regarded it: Ethics, I, prop. 33, schol. 1). It is natural to conclude that for Leibniz, as Lovejoy has put it, "though we are unable to attain an intuitive apprehension of the necessity [of a judgment which appears to us as contingent], ... we can nevertheless be sure that the necessity is there, and is recognized by the mind of God." ${ }^{34}$ Russell took a similar view in 1903, when he wrote, "Where an infinite analysis, which only God can perform, is required to exhibit the contradiction, the opposite will seem to be not contradictory"; he did not think the alternative suggestion, "that the denial of an analytic truth might be not selfcontradictory," would commend itself to Leibniz. ${ }^{35}$

This objection rests on a fundamental misunderstanding of Leibniz's conception of necessity and contingency. The distinction between them "is drawn on logical grounds alone, "as Rescher rightly points out. ${ }^{36}$ It is not an epistemological distinction, and is not based on a relation in which contingent propositions stand to us but not to God. It is based on a difference in the logical form of the reasons by virtue of which propositions of the two sorts are true. Contingent truths are just as contingent for God as they are for us, and $\mathrm{He}$ can no more demonstrate them than we can; for not even He can "see ... the end of the analysis, since there is no end" (FC 182, 184/L 265f.). ${ }^{37}$ Leibniz does say that God can know contingent truths a priori (that is, through their reasons), and that we cannot. But these epistemological relations are not constitutive of contingency; they are only consequences of the logical property that is constitutive of contingency.

Two initially plausible principles about (logical) necessity are that whatever is true purely by virtue of the relations of concepts is necessary, and that whatever is necessary must be logically demonstrable. Leibniz seems at first to have assumed both of these principles. The light that was kindled for him by the knowledge of the analysis of infinites (C 18/SG 348) was the realization that the two assumptions are incompatible because some propositions that 
are true solely by virtue of the relations of concepts are nonetheless not provable by anything that he would count as a demonstration. Leibniz held consistently to the second principle. His usual definition of the logically necessary is that it is that whose contrary implies a contradiction (e.g., Preliminary Discourse to the Theodicy, §2). And we have seen that Leibniz treats "implies a contradiction" as expressing a proof-theoretical property that does not belong to propositions whose falsity can be discovered a priori only through an infinite analysis (FC 181/L 264; cf. C 17/SG 346f.). The realization of the incompatibility of the two principles therefore enabled Leibniz with a clear conscience to give up the first principle, which had made his theory of truth seem to leave no room for contingency.

When Russell charged that the infinite analysis conception of contingency would at most yield truths that only seem to be contingent, he was explicitly and mistakenly assuming that whatever is false purely by virtue of the relations of concepts must be self-contradictory for Leibniz. Similarly Curley seems to be assuming a conception of necessity in terms of conceptual truth, rather than in terms of demonstrability, when he says that the bestness of this world "is not rendered any the less necessary by the number of other possible worlds being infinite rather than finite." ${ }^{38}$ For our own use, of course, we may well prefer a conceptual truth conception of necessity to a demonstrability conception. If so, we will rightly conclude that Leibniz's infinite analysis theory does not give us real contingency. But that presents no internal objection to Leibniz's system. The contingency we are demanding, he can only regard as a brute fact and a violation of the principle of sufficient reason, which he has no intention of admitting in his mature philosophy.

It is just as clear in the essay "On the Radical Origination of Things" (G VII,302-308/L 486-491 [November 23, 1697]) as in the letter to Wedderkopf (A II,i,117f./ L 146f. [May 1671]) that Leibniz thinks of everything in the world as determined ultimately by the divine nature, and particularly by the relations of concepts in God's intellect. From this point of view the problem of contingency is to find a difference between ways in which facts are determined by relations of concepts-a difference that is both important and plausibly related to the preanalytic notions of logical necessity and contingency. The difference between truths that are and that are not demonstrable in a finite number of steps fills this role admirably.

\subsection{Contingent Connections among Possibles as Such}

As a consequence of his infinite analysis theory of contingency Leibniz accepted another thesis which some commentators have been most reluctant to admit as part of his philosophy. Russell noted in 1903 that "the view that infinite complexity is the defining property of the contingent has the curious consequence that truths about possible substances are contingent." ${ }^{39}$ Both Broad and Curley have claimed that Leibniz did not accept this consequence, ${ }^{40}$ 
but their claim is untenable. That you exist in the best possible world is a fact about you conceived as a possible substance; but its contingency follows from what Leibniz wrote in several places about the contingency of which world is best.

Indeed the idea that there are contingent connections among things considered as possible becomes quite important to Leibniz in the Discourse on Metaphysics and correspondence with Arnauld. This is to be expected, in view of Leibniz's insistence that all of the acts of any individual follow from the concept of that individual considered as possible. If it is important to our freedom that we be contingently connected with our actions, this following of our actions from our concepts must somehow be a contingent connection between them and us considered as possible. Accordingly Leibniz says in $\$ 13$ of the Discourse that there are two sorts of connection, one absolutely necessary but the other contingent, by which different events follow from the complete concept of a created person.

Arnauld was perhaps the first to find this strange. He argued that on Leibniz's view, the connection between Adam and everything "that has happened and will happen to him and his posterity" must be necessary, "because," as Leibniz put it, "I consider the individual concept of Adam as possible," and "possible concepts in themselves do not depend on the free decisions of God" (G II,28-30, 40/L-A 28f., 42f.). There are two main points in Leibniz's reply to this objection.

(a) "The possibles are possible before all the actual decisions of God, but not without presupposing sometimes the same decisions taken as possible" (G II,51/L-A 56). This is because the complete concept of any possible thing involves (as possible) some decisions that God would make (for instance, in establishing laws of nature) if $\mathrm{He}$ actualized the world to which that thing belongs. Here Leibniz clings to the idea that truths involving God's decisions are contingent. But now it seems they need not depend on what He actually decides; it is enough if they involve divine decisions considered as possible. Why the merely possible divine decisions should be thought to have this relevance is obscure to me.

(b) The connection between a person, considered as possible, and the events of his possible world is "intrinsic" (G II,51/L-A 56) and "certain" but not "necessary," although the failure of the connection would destroy the individual concept of the person (G II,52/L-A 58; cf. G II,41/L-A 44). Here Leibniz seems to be quite clear that his position involves contingent connections within possible worlds, and hence contingent truths that do not depend on God's actual decisions, nor on which world is actual. ${ }^{41}$

The same view is expressed by Leibniz in other texts.

It is of the nature of an individual substance that its concept be perfect and complete, and contain all its individual circumstances, even contingent ones, down to the least detail.... Yet these individual [circumstances] are not therefore necessary, and do not depend on the 
divine intellect alone, but also on decisions of the divine will, insofar as the decisions themselves are considered as possible by the divine intellect. ( $\mathrm{Gr} 311$ [1683])

About 1695 , in a reading note, he stated flatly, "There are some indemonstrable truths even in possible things-namely about contingent things regarded as possible" (Gr 353). And probably a little later he wrote that "God decided to create a creature whose full concept involves such a series of graces and free actions, although not necessarily but by such a connection as the nature of the thing involves" (Gr 383 [1697]).

How can the connection between an individual substance and some of the properties or events involved in its concept be contingent? Leibniz offers hints of some answers to this question, but they are by no means so clear as his best-worked-out answers to the question how the existence of those creatures that are actual can be contingent. Three answers may be distinguished.

(1) In $\$ 13$ of the Discourse Leibniz says that the predicate of deciding to cross the Rubicon and winning the battle of Pharsalus is contained in the concept of Julius Caesar, but that it is not "necessary in itself" that those things happen to him. This suggests that Leibniz thought of Caesar's deciding not to cross the Rubicon, or his losing at Pharsalus, as things that are possible in themselves, in the same way that non-actual possible worlds are possible in themselves, although they are impossible on the hypothesis of something else. But it is hard to make sense of this suggestion, if the source of the threatening necessity is in Caesar's own complete concept. That would seem to constitute a necessity internal to Caesar's deciding and winning.

In the case of possible worlds I suggested ${ }^{42}$ a distinction between the complete concept of a world and a fragment of it, the world's "basic" concept; only what is contained in its basic concept determines whether a world is possible in itself. Leibniz had the similar idea that properties and events that are contingently contained in the complete concept of an individual substance are distinguished by not following from any incomplete and general fragment of it. Thus in explaining to Arnauld how "the connection of events, though it is certain, is not necessary," and how he is free in taking a journey that is contained in his complete concept, Leibniz says,

And there is nothing in me, of all that can be conceived as general, or as essence or specific or incomplete concept, from which one can infer that I shall take it necessarily; whereas from the fact that I am a man one can conclude that I am able to think. (G II,52/L-A 58)

Similarly Leibniz writes that the complete concept of Peter as possible contains "not only essential or necessary [matters], which derive, that is, from incomplete or specific concepts, ... but also ... existential (so to speak) or contingent [matters]" (Gr 311 [1683]). The use of "essence" and "essential" here is significant. In the Discourse on Metaphysics Leibniz identified the "essence" with the "individual concept" of a substance (DM 16), but in a later paper he distinguished them, using "essence" to refer to a fragment of the 
individual concept to which he attributed particular importance for modality:

Of the essence of a thing is what belongs to it necessarily and perpetually; of the concept of a singular thing, however, is also what belongs to it contingently or by accident, or what God sees in it when He has perfectly understood it. ( $\mathrm{Gr} 383$ [1697])

But whereas the basic concept of a possible world suffices to distinguish it from all other possible worlds, an essence or specific concept of Caesar that left out his decision to cross the Rubicon would not suffice to distinguish him from all other possible individuals, for "a concept that is still indeterminate even in the slightest circumstances . . . could be common to two different individuals" (Gr 311). It seems strange to say that Caesar's deciding not to cross the Rubicon is possible in itself on the ground that his decision to cross is not contained in a concept that he shares with one or more other possible individuals.

(2) A more plausible idea can be read into the statement, in $\S 13$ of the Discourse, that if someone did the opposite of something that is involved in his complete concept, "he would do nothing impossible in itself, although it is impossible (ex hypothesi) for that to happen." Maybe just as God chooses freely because $\mathrm{He}$ chooses among a plurality of possible worlds, each of which is possible in itself even if it is impossible in relation to God's choice, so a creature can act freely because he chooses among a plurality of actions, each of which is possible in its own nature even if it is impossible in relation to the complete concept of the choosing creature. If this is to work, the alternatives for choice must be regarded as somewhat general, rather than as completely individual actions. Caesar's alternatives on the bank of the Rubicon, for example, must be crossing and not crossing, rather than Caesar's crossing and Caesar's not crossing. Individual concepts must be kept out of the objects of choice. This line of thought, therefore, does not show us a way in which Caesar's deciding to cross the Rubicon can be contingent. But it does show us a way in which Leibniz should say that the reality of Caesar's choice is preserved. I am not sure that Leibniz really had in mind this treatment of the freedom of created spirits, but it would have been worth developing.

(3) Contingent connections between possibles can be explained in terms of the infinite analysis theory of contingency. Leibniz gives such an explanation of the contingency of "Peter denies": "The concept of Peter is complete, and so involves infinite things; therefore one never arrives at a perfect demonstration" (C 376/P 66). Leibniz does not say here whether Peter is considered as actual or merely as possible. But the argument evidently works just as well as if the subject is considered only as a possible person-as Russell perceived with dismay.

There are even more difficult problems, however, about how infinite analysis is supposed to work in this case than in the case of bestness among possible worlds. Leibniz mostly ignores these difficulties, and I cannot do 
much more here than point them out. The first is the problem of the Lucky Proof. ${ }^{43}$ Even if infinitely many properties and events are contained in the complete concept of Peter, at least one of them will be proved in the first step of any analysis. Why couldn't it be Peter's denial? Why couldn't we begin to analyze Peter's concept by saying, "Peter is a denier of Jesus and . .."? Presumably such a Lucky Proof must be ruled out by some sort of restriction on what counts as a step in an analysis of an individual concept, but so far as I know, Leibniz does not explain how this is to be done. On the other hand, we may wonder how we can even begin an analysis of the individual concept of any person, as Leibniz implies we can. For such a concept, being complete, is not our concept but God's, and we do not seem to have a definition with which to begin to replace it. ${ }^{44}$

\subsection{Reasons that Incline without Necessitating}

One of the things Leibniz never tired of saying about free choices is that their causes, motives, or reasons "incline" but do not "necessitate." Lovejoy called this "misleading if edifying phraseology," and a "verbal distinction, absolutely meaningless in the light of [Leibniz's] other doctrines." 45 One is tempted to agree with this harsh judgment, for Leibniz does not give much explanation of the difference between inclining and necessitating. But I think the distinction has a place in the interpretation of Leibniz we have been developing.

Leibniz presents the idea of reasons that incline without necessitating, sometimes in connection with the notion of a choice among alternatives that are possible in themselves (T 45, 230; to Clarke, V,8-9), and sometimes in connection with the infinite analysis theory of contingency. In the latter connection, which seems to me the more illuminating of the two, Leibniz says, "There is the same proportion between necessity and inclination that there is in the Mathematicians' Analysis between exact Equation and limits that give an approximation" (Gr 479; cf. Gr 303 and G VI,414 [Remarks on King, $\S 14])$.

The preceding statement was written about 1702 in a memorandum that also makes clear how infinity is supposed to enter into the influence of reasons on the will. The word "incline" suggests the image of a balance that is tipped or inclined to one side or the other by the preponderance of weights; and "balance" (noun and verb) occurs, at least figuratively, several times in the memorandum. Leibniz liked mechanical analogies for volition (T 22, G VII,304/L 488), and in particular that of the balance (cf. NE II,xxi,40). He later wrote to Clarke $(\mathrm{V}, 3)$ that "reasons in the mind of a wise being, and motives in any mind whatsoever, do that which answers to the effect produced by weights in a balance." Though not necessitating, the balance of motives determines as certainly as the balance of weights. "We always follow the direction toward which there is more inclination or disposition" ( $\mathrm{Gr} 479$ ); we never fail to do so ( $\mathrm{T} 43$ ). 
The motives that play the role of weights in the scales of volition include all our perceptions, subconscious as well as conscious, according to Leibniz.

Several perceptions and inclinations contribute to the complete volition, which is the result of their conflict. Some of them are separately imperceptible; the mass of these makes an uneasiness which pushes us without the subject of it being seen (NE II,xxi,39; cf. Gr 480).

Here the infinite makes its appearance. For in Leibniz's system the mass of subconscious perceptions in a finite spirit is a confused perception of the whole universe, in all its infinite complexity. Every fact about the world is perceived, and our perception of it has some influence on our will; those perceptions of which we are not conscious are nonetheless weighed in the balance en masse, by virtue of their contribution to our feelings. Our minds, being finite, cannot completely understand the motives of our choices, because they are infinitely complex. On the same ground the connection between a free decision and its ultimate reasons or motives will be contingent, and cannot be demonstrated, in the senses laid down in the infinite analysis theory of contingency. Much of this, including some connection between contingency and the infinity of influences, is explicit in the memorandum quoted above. Leibniz speaks there of our ignorance "of an infinity of little influences on us of which we are not conscious," which sometimes lets us have the illusion that the factors moving our will are equally balanced. And he immediately adds,

That shows that it is indeed always true that our freedom, and that of all other intelligent substances right up to God Himself, is accompanied by a certain degree of indifference or contingency, which has been defined in such a way that we and those substances are never necessitated, since the contrary of that which happens always remains possible or implies no contradiction. (Gr 480f.)

The reference to God should not be taken as suggesting that God has subconscious motives; for Leibniz's God perceives everything distinctly. But Leibniz did say that "God had infinite reasons competing with each other, which $\mathrm{He}$ considered when $\mathrm{He}$ judged this possible universe worthy to be chosen"; he offered it as an explanation of why the truth of "This series of the universe is the best" cannot be known a priori by us (Gr 343). God's reasons, like ours, incline but do not necessitate, because they are involved in a conflict of such infinite complexity that the resulting volition cannot be demonstrated (in the strict sense) from them. ${ }^{46}$

\subsection{Is "God chooses what is best" Contingent?}

The contingency of "God chooses this world" could be explained and defended by holding either that "God chooses what is best" is contingent or that "This world is the best" is contingent. We have seen that Leibniz prefers the latter alternative; but he explicitly rejects the other in only one of the texts we examined. More often he leaves open the possibility of holding that both are contingent. There seems to have been more vacillation and uncertainty in 
Leibniz's mind about whether it is necessary or contingent that God chooses what is best than about any other main issue in the problem of contingency. I shall argue, however, that the view that it is necessary is required by other features of Leibniz's philosophy.

Many passages in which Leibniz appears to address this issue yield no solid evidence on it, in view of some of the subtleties that we have already seen in his position. When he says, for example, "God's decisions about contingents certainly are not necessary" (Gr 385$)$, the claim can be taken de re with respect to the contingents: for any contingent, what God decides about it is not necessary (because it takes an infinite analysis to determine what is best). It may not be implied, therefore, that it is not necessary that God decides to order contingent things as well as possible. Similarly, when Leibniz says that "God was infallibly led by His wisdom and goodness ... to give [the world] the best form possible; but He was not led to it necessarily" (G VI,414 [Remarks on King §14]), the expression "to it" (in French " $y$ ") does not make clear whether the denial of necessity applies de re to that form which is the best possible for the world, or whether it applies de dicto to God's giving the world whatever form is best. We have to bear in mind Leibniz's saying that "it is a necessary proposition" that God wills the best, but He does not will it "necessarily," because what is best is not necessarily so (Gr 493f.).

On the other hand, our present question remains equally unanswered when Leibniz says, as he often does, such things as "God cannot fail to choose the best" (see T Abridgement, VIII). For Leibniz has distinguished several sorts of inability and necessity. He may mean only a moral necessity (as he says, ibid. [G VI,386]); whereas we are interested in logical or metaphysical necessity.

And when Leibniz says that "God wills the best by His own nature" (Gr 289 ), or that the reason for His eternal free action is "the divine nature or perfection itself" (C 405), he says nothing more than is implied by his analytic theory of truth. What we want to know is whether God's voluntary optimizing is demonstrable - that is, whether it follows by a finite or only by an infinite analysis from the divine nature. In fact, in both the texts I have just quoted on this point, it is stated or suggested that it is not demonstrable ( $\mathrm{Gr} \mathrm{288,C} \mathrm{405).}$

First of all, therefore, we must seek texts in which necessity is asserted or denied, de dicto, of some such propositions as "God chooses what is best," and in which the necessity is explicitly or contextually indicated as logical or metaphysical, or is stated or explained in terms of demonstrability. There are several such texts, and they speak on both sides of the question.

The most explicit texts for the contingency of the crucial propositions date from about 1681, when Leibniz was actively engaged in formative work on a variety of solutions to the problem of contingency. He had already written, in "Necessary and Contingent Truths," that "in a certain way it is of physical necessity [which he had distinguished there from metaphysical necessity] that 
God does all things as well as He can" (C 21/SG 351). But about 1681 he denied flatly that the proposition, "that God chooses the best," or "God wills to choose the best," can be demonstrated (Gr 301$).{ }^{47}$ A contrast is introduced in a similar denial in another paper from about the same time:48 "Thus, that God loves Himself is necessary, for it is demonstrable from the definition of God. But that God does what is most perfect, cannot be demonstrated, for the contrary does not imply a contradiction" (Gr 288).

The contrast recurs in some later texts. In the early 1690 s Leibniz noted with approval Thomas Aquinas's opinion "that God's attitude toward Himself is necessary and natural, but His attitude toward other things is not necessary, nor forced, but voluntary" (Gr 333). ${ }^{49}$ And in the Theodicy, he says, "The love that God has for Himself is essential to Him; but the love of His glory, or the will to obtain it, is not essential to Him at all" (T 233; cf. T 175,230 ). (Here God's glory is conceived as an external attribute, "the reflection of the divine perfection in created beings." ${ }^{50}$ )

The contingency of "God chooses what is best" seems more favored in the Theodicy than in the private papers Leibniz wrote while preparing the book. In addition to this passage about God's love of His glory, there is a list of things said to be necessary "in a certain sense," but not "logically, geometrically, or metaphysically"; among them is "that God Himself chooses the best" (T 282; it would not be plausible to read this denial of logical necessity as de re with respect to the best). If the Theodicy were our only source for Leibniz's opinions, I think we would find nothing incompatible with the impression that Leibniz thinks it contingent, de dicto, that God chooses what is best. And the general tenor of the book would leave us with that impression, although most passages in it can be interpreted otherwise in the light of his other works.

Section 13 of the Discourse on Metaphysics gives a similar impression. Probably the most important utterance bearing on the issue there is the mention of "the first free decision of God, the import of which is to do always that which is most perfect." For if this decision is free and freedom implies contingency, it will follow that "God decided to do what is best" is contingent.

The strongest texts on the other side are those already discussed in section 2.1 above, in which Leibniz pointedly refrains from denying, and in 1706 affirms, that "God chooses the best" is logically necessary. Those texts date from about 1689 to 1706 ; but there is an earlier note, from about 1681 , in which Leibniz says, "From God's essence or supreme perfection it follows, certainly and, so to speak, by a necessary implication, that God chooses the best" (Gr 297). He goes on to explain God's freedom in terms of the plurality of alternatives possible in their own nature. The phrase "by a necessary implication" is important here. When Leibniz wrote in 1698 that "it follows from the nature of God that He prefers the most perfect" (Gr 393), he left some ambiguity. For he also said that all truths, even contingent ones, follow from God, who is the highest truth (Gr 347). Might God's preference for 
perfection follow from His nature by an infinite rather than a finite analysis, and therefore contingently? But what follows from God's essence "by a necessary implication" must be necessary-though the qualification "so to speak" or "if you will" ("si ita loqui placet") still leaves a little uncertainty.

In reading notes from the 1690 s Leibniz held that "the inability to do evils can be demonstrated in God" (Gr 333) and "rigorously, it can be said that the good Angels can sin, and that does not imply a contradiction, but in God it does imply one" ( $\mathrm{Gr} 360)$. Leibniz held more consistently to this thesis than to the more general claim that it is demonstrable that God chooses the best. Even in one of the papers from about 1681 in which he states flatly that "God chooses the best" is not demonstrable, Leibniz says that damning the innocent eternally is not possible for God and is therefore one of those things "whose ... existence implies a contradiction" (Gr 300).

The only text against this of which I am aware is in the Theodicy: "However it does not imply a contradiction for God to will (directly or permissively) a thing that does not imply a contradiction" (T 234). Nothing is said here explicitly about whether it is contingent, de dicto, that God does no evil or that God chooses the best. For the possibility that is asserted is pretty clearly de re with respect to the objects of God's choice: it is claimed about everything, that if it is possible in itself, considered without regard to its relation to God's will, then it is also possible for God to will to actualize it. But since Leibniz thought the eternal damnation of the innocent is possible in itself (Gr 300), it does follow that it is possible for God to damn the innocent eternally - which is not far removed from the conclusion that it is possible for God to do evil.

In general, however, Leibniz seems inclined to the view that it is demonstrable that God does no evil, whether or not it is demonstrable that $\mathrm{He}$ chooses the best. Indeed, even his 1706 reading note on Bayle in which he says that "God wills the work that is most worthy of Him" is a necessary proposition ends with a hint that God "cannot do or will moral evil" in some sense stronger than that in which $\mathrm{He}$ cannot fail to create the best possible world (Gr 494).

But if Leibniz holds that it is demonstrable that God does no evil, how can he avoid the conclusion that it is demonstrable that God does not prefer the less perfect? "For as a lesser evil is a kind of good, by the same token a lesser good is a kind of evil, if it forms an obstacle to a greater good" (T 8). And in maintaining the axiom, "Minus bonum habet rationem mali" ("A lesser good has the character of an evil") (T 194, D M 3, G III,33), Leibniz does not suggest that it is contingent. So it seems that preferring the less perfect would necessarily be doing something evil.

God is more than sinless. That "God is an absolutely perfect being," morally as well as metaphysically, is virtually a definition for Leibniz (DM 1); and so far as I know he never suggests that it is contingent. If it is not true by definition, 
or at least demonstrable, how is he so confident that it is true at all? Surely he does not know it by experience. And he denies that it is known only by faith (T Preliminary Discourse 44). Both Rescher and Curley seem to me to err in saying that Leibniz would solve the problem of contingency by holding that God's goodness is contingent. ${ }^{51}$

But that is not the only way in which he could deny that it is necessary that God does what is best. For the belief that God does what is best is based on two premises: that God is "a most perfect Being," and that "the operation of a most perfect Being is most perfect" (Gr 16). And Leibniz did once say that the second of these is contingent: "God's choosing a less perfect from among many perfect things does not imply an imperfection in God" (Gr 300 [about 1681]). I agree with this statement, 52 but find it astonishingly un-Leibnizian and do not think it fits in his philosophical system.

One objection to including it in the system is inconclusive. Leibniz says it is morally necessary for God to choose the best. And this means that it is necessary that a perfectly good agent in God's position would choose the best (see section 1.5 above). It follows that it is necessary that if God chooses the less perfect, He is imperfect (cf. G III,33). But the crucial question here is whether this is a logical necessity. Is the morally necessary only what it is demonstrable that a perfectly good agent would do? Or is it enough for moral necessity if the action is contained in the concept of a perfectly good agent, even though an infinite analysis would be needed to show the reason of the containment? The weaker requirement seems to me to be the one assumed in Leibniz's mature writings. For he appears to regard God's choice of this world as morally necessary (cf. T Preliminary Discourse 2); but it is not demonstrable that a perfectly good agent would choose this world, since it is not demonstrable that this world is the best.

There are other arguments, however, which show that Leibniz cannot consistently hold that it is contingent that a supremely perfect being would choose the more perfect. For suppose that is contingent. Then it must either be contingent that a supremely perfect being is perfectly good, wise, and just; or else contingent that a perfectly good, wise, and just being would choose the more perfect. Neither of these is contingent for Leibniz.

For he regards justice as "an essential attribute of God" (Dutens IV,iii,280; this is not asserted but contextually implied there). And since God's justice, for Leibniz, "depends on wisdom and goodness" (Dutens IV,iii,261; cf. G III,34), the latter perfections must presumably be regarded as essential to God too.

Leibniz would also have to admit that it can be demonstrated, from acceptable definitions of these perfections, that they imply a preference for the best. For he says,

The end of goodness is the greatest good, but in order to recognize it, wisdom is needed, which is nothing other than knowledge of the good, as goodness is nothing other than the 
inclination to do good to all, and to prevent evil unless it is necessary for a greater good or to prevent a greater evil. ${ }^{53}$

Thus Leibniz seems unable to escape the conclusion that it is demonstrable, and hence logically necessary, that God, as an absolutely perfect being, does what is best.

The conflict in Leibniz's thought is reflected in divergent pronouncements about "the root of contingency." About 1683 he set out, somewhat tentatively, the idea that in dealing with problems of contingency we must "have recourse to that one thing which is not essential in God, but free-namely, the decision of the will, from which alone a source of contingency in things can be sought" (Gr 311). This is not unambiguous, but seems to agree with Rescher's judgment that for Leibniz "the ultimate source of contingent truth is clearly" in God's choosing "to act in the most perfect way," rather than in the bestness of that which is chosen. ${ }^{54}$ But elsewhere Leibniz locates the root of contingency, not in the divine will, but in the objects among which God chooses. About 1681 he wrote, "The root of freedom in God is the possibility or contingency of things"-by which he means the plurality of alternatives possible in themselves, as the context shows (Gr 298). About 1695, likewise, he wrote notes on the views, ascribed to Scotus and Aquinas respectively, that the root of contingency is in the will of God as free, and that it is in the will of God as efficacious. Leibniz commented on the former view that it was circular, and on the latter that "contingency is in the nature itself of truth, or of the object, as of possibility, as of existence" (Gr 348; cf. Gr 353). Here perhaps what he has in mind is that contingent truths cannot be proved by a finite analysis.

The circle with which Leibniz charged Scotus has to do, presumably, with seeking the ultimate reason for all contingent facts in a divine decision which is itself one of the contingent facts to be explained. Often Leibniz sees an infinite regress in place of this circle, and almost always he condemns it as vicious. There is one text, however, in which he accepts the infinite regress; and this acceptance assumes great importance for the interpretations of Rescher and Curley.

The first principle about Existences is this proposition: God wills to choose the most perfect. This proposition cannot be demonstrated; it is the first of all propositions of fact, or the origin of every contingent existence.... For if anyone asks me why God decided to create Adam, I say: because $\mathrm{He}$ decided to do what is most perfect. If you ask me now why $\mathrm{He}$ decided to do what is most perfect,... I answer that He willed it freely, or because $\mathrm{He}$ willed to. Therefore $\mathrm{He}$ willed because $\mathrm{He}$ willed to will, and so on to infinity. (Gr 30lf.)

Curley says that this text presents "the only one of the various ways in which Leibniz invokes infinite processes which seems ... to have any bearing on the problem of contingency." 55 Rescher does not cite this passage, but proposes, as Leibniz's main solution of the problem of contingency, that "God's moral perfection follows from His metaphysical perfection, but the 
deduction would require an infinity of steps." 56 Something of this sort is required, of course, if the supposed contingency of "God chooses what is best" is to be reconciled with Leibniz's analytic theory of truth and infinite analysis theory of contingency.

Rescher's formulation deftly avoids the obvious objection that the infinite regress of reasons violates the principle of sufficient reason. Leibniz's use of the principle in proving the existence of God requires him to refuse to accept an infinite regress of reasons as itself constituting a sufficient reason. Furthermore Leibniz had said "it is absurd [to suppose] that a free will is an ultimate reason, since the free will itself has its necessary conditions [requisita], for it is not an independent Being [Ens a se]" (Conf 46 [a marginal comment, probably from late 1677 or early 1678]). A sufficient reason must be found in something of metaphysical necessity; the ultimate reason for the existence of all things is to be found in the divine essence and intellect. Rescher recognizes and accepts this. On his interpretation the ultimate sufficient reason is found in God's metaphysical perfection; if there is an infinite regress of volitions, it has a reason outside itself in God's nature. But in conformity with the infinite analysis theory of contingency, this reason cannot be proved by a finite analysis.

In the paper in which he accepts the regress, however, Leibniz was not so deft as Rescher. For he refused there to ground the infinite regress of volitions in God's essence. "No other reason can be given why God chooses the most perfect than because $\mathrm{He}$ wills to ... And certainly $\mathrm{He}$ wills freely, because outside His will no other reason can be given than the will." He goes on to claim that "nothing is therefore given without a reason, but that reason is intrinsic to the will" (Gr 301). But the infinite regress of volitions he describes certainly does not satisfy his principle of sufficient reason.

It is noteworthy, moreover, that this rather early paper contains no explicit appeal to the infinite analysis theory of contingency. I know of no work in which Leibniz develops the infinite regress of volitions into the sort of solution that Rescher proposes for him.

For this text, as Grua says (Gr 259), is exceptional. It is the same short paper in which Leibniz denied that choosing the less perfect would imply an imperfection in God. And the infinite regress of volitions, and the whole idea of willing to will, were explicitly rejected by Leibniz, at about the same time as well as both earlier and later. About 1681 he wrote, "Indeed God cannot will voluntarily; otherwise there would be a will to will [and so on] to infinity" (Grua 289). In the letter to Wedderkopf and in The Philosopher's Confession he had denied, with explicit reference to God, that anyone wills what to will (A II,i,117/L 147) or wills because he wills (Conf 54). In the New Essays Leibniz says, "We do not will to will, but we will to do; and if we willed to will, we would will to will to will, and that would go to infinity" (NE II, xxi,22-23). Here nothing is said explicitly about God. But there is explicit reference to 
God in the Theodicy where Leibniz says, "It is, in a sense, an abuse of terms to say here: one can will, one wills to will; power is related here to the actions that one wills" ( $\mathrm{T}$ 234).

There are, it must be granted, two texts that support the idea that divine decisions, considered as possible, are part of the object of other divine decisions (C 24), or more vaguely, that "God executes all reflex acts at once and once for all" (Gr 345). And indeed Leibniz thought of possible divine decisions as involved in the concepts of possible creatures among which God chooses. But in these texts it is not stated or suggested that God's general decision to do what is best is the object of a prior decision, nor that the regress of decisions provides the reason for the decision to act.

At any rate the infinite regress of volitions is clearly not a keystone of Leibniz's position on contingency. On this as well as other grounds that we have reviewed, it is fair to say that the view that "God chooses what is best" is contingent must not be regarded as a thesis of Leibniz's philosophy, much less as a basis of one of his principal solutions to the problem of contingency.

\subsection{An Exception for Existence?}

We are now in a position to deal with the question whether Leibniz meant to solve the problem of contingency by making existence an exception to the rule that the predicate of a true proposition must be contained in the concept of the subject. There are several compelling arguments for a negative answer.

(1) Leibniz says something that looks very much like an explicit negative answer, in the New Essays:

But when one says that a thing exists, or that it has real existence, this existence itself is the predicate-that is to say, it has a concept linked with the idea that is in question, and there is a connection between these two concepts (NE IV,i,3-7). ${ }^{57}$

(2) In many formulations of his analytic theory of truth Leibniz says explicitly that the concept of the predicate is contained in the concept of the subject in contingent as well as necessary truths (FC 179/ L 263f.; G II,56/ L-A 63; C 16/SG 346; C 519/L 267f.; C 272; G VII,199f.; Gr 303). In view of these statements, it seems perverse to suppose that Leibniz meant to explain the possibility of contingency by making an exception to the theory for those propositions that he regarded as contingent.

(3) Leibniz made a number of attempts to explain how existence is contained in the concepts of those things that exist. These attempts typically involve some or all of the following claims. The predicate of existence is in some way equivalent to "entering into the most perfect series of things" (C 9; cf. Gr 325, B 119f., C 405, C 360, 376/P 51, 65f.), or to pleasing God (C 405; cf. C 376/P 65f.). The analysis of concepts would have to be carried to infinity, however, to prove the existence of any contingent thing (C 376/ P 66; 
cf. Gr 304f.). The underlying idea, of course, is that existence is contained in the concepts of existing things, not directly but by virtue of the factors that determine God to create those things.

(4) As Couturat pointed out, "existential propositions are not the only contingent propositions" for Leibniz. ${ }^{58}$ Couturat chose an unfortunate example: laws of nature, which are indeed contingent, but are also existential according to Leibniz, as Curley has pointed out. ${ }^{59}$ But in sections 2.1 and 2.3 above we have seen better examples of contingent propositions whose truth, according to Leibniz, does not depend on what exists-namely, the propositions asserting the bestness of this possible world and the contingent connections within possible worlds.

(5) The version of the problem of contingency that troubled Leibniz most persistently throughout his life does not depend on his conception of the nature of truth, and cannot be solved by making the predicate of existence an exception to that conception. For the problem is that the existence of all actual things seems to follow, not just from their own concepts, but from the concept of God, whose existence Leibniz always regarded as necessary.

There are some texts, however, that seem to speak on the other side of the question. Foremost among them is a passage near the end of the early paper "Necessary and Contingent Truths." The paper seems somewhat confused on the point that concerns us. For although it contains a statement that the concept of the predicate is contained in the concept of the subject even in contingent truths (C 16), and an effort to explain how the existences of contingent things are involved in their concepts, it also contains the statement, "For the possibility or Concept of a created mind does not involve existence" (C 23). The most favorable interpretation that we can put on this statement is that Leibniz is groping after the distinction that he later articulated between the complete concept of a thing and its essence (Gr 383). The essence or specific concept of any created substance would not contain the existence of that substance, although the complete concept would. As was noted in section 2.3 above, this distinction does not seem to me to serve the purpose of rendering propositions contingent in themselves.

It is a distinction that is needed, however, to bring into any sort of tolerable harmony with the rest of Leibniz's system the fairly numerous texts in which he treats "essential" and "existential" as equivalent, respectively, to "necessary" and "contingent." In some of these texts, indeed, he explains "essential" in terms of things that "flow from incomplete and specific concepts" ( Gr 311; cf. Gr 383). In other texts he leaves the sense of "essential" unexplained ( $\mathrm{Gr} 354,373$ ); and he never manifests any concern about reconciling his use of "existential" with the fact that he holds, and his system implies, that some contingent truths do not depend on which finite things actually exist. It is difficult to shake off the impression that Leibniz was subject to some persistent confusion on this point. 


\section{Leibniz and Possible Worlds Semantics}

It has been discovered that by beginning with the idea that the possible is what is true in some possible world and the necessary is what is true in all possible worlds, and varying our assumptions about the relations of possible worlds to each other, we can obtain models that validate different systems of modal logic. This discovery has given birth to possible worlds semanticsthe interpretation of modal notions in terms of truth and falsity in (or at) possible worlds. It has shed so much light on modal logic, and has so affected our interest in the notion of possible worlds, that it is especially natural for us to assume that Leibniz too conceived of necessity as truth in all possible worlds and contingency as truth in some but not all possible worlds. But it is not at all clear that he did.

Probably the closest he comes to expressing this conception is in the early paper on "Necessary and Contingent Truths," where he says that necessary truths, which can be demonstrated by analysis of terms, "not only will obtain while the World stands, but also would have obtained if GOD had created the World on a different plan" (C 18/SG 348). This is suggestive but not conclusive; for on any reasonable interpretation of Leibniz, he regards no world as possible in which something demonstrable is false (if we overlook the problem about the damnation of the innocent that was discussed in section 2.2 above). What we want to know is whether he thought that all the truths that do not depend on which world God created are necessary. He almost says that they are. He says that contingent truths, which cannot be demonstrated by analysis, "do not express only what pertains to the possibility of things, but also what actually exists, or would be going to exist if certain conditions were satisfied" (C 18/SG 348). In this statement it is not clear whether the counterfactual conditional is supposed to rest on causal laws, in which case its truth depends on which world is actual, or whether it just means "would exist in some possible world." But the initial parts of "Necessary and Contingent Truths" seem to me in general to reflect the assumption that contingent truths depend on which world is actual.

On the other hand, Leibniz regarded as contingent some truths which he would hardly have regarded as depending on which world God actualized. The most obvious example in this category is the proposition that this world is the best possible.

The first step in dealing with this problem is to distinguish two things Leibniz may mean by "possible world." He may mean a world whose concept is not demonstrably inconsistent, or he may mean a world whose basic concept does not involve (demonstrably or otherwise) a contradiction or conceptual falsehood.

The first of these interpretations fits with Leibniz's usual conception of necessity in terms of demonstrability, and indeed yields a possible worlds semantics for it. Because it is plausible to suppose that not all conceptual 
truths are demonstrable, the conceptual truth and demonstrability conceptions of necessity demand different modal logics. The strong system S 5 seems to be the right modal logic for the conceptual truth conception of necessity. ${ }^{60}$ But the characteristic axiom of S5, " N $p \supset \mathrm{N} \sim \mathrm{N} p$ " (if not necessarily $p$, then necessarily not necessarily $p$ ), is not valid on the demonstrability conception of necessity. For a proposition may be indemonstrable without being demonstrably indemonstrable. (In rejecting this axiom, it should be noted, one rejects the assumption that all truths about the possible as such are necessary.) The weaker system S4 seems to be the right system for the demonstrability conception of necessity. Its characteristic axiom, "Np $\supset \mathrm{NN} p$ " (if necessarily $p$, then necessarily necessarily $p$ ), will be valid under that conception; for what can be demonstrated can thereby be demonstrated to be demonstrable.

By the same token, if we assume that a world $w_{2}$ is possible in a world $w_{1}$ if and only if nothing is true in $w_{2}$ whose falsity can be demonstrated in $w_{1}$, we obtain the result that the relation among possible worlds expressed by "possible in" is reflexive and transitive but not symmetrical. It is reflexive, if we restrict consideration to worlds that are possible (that is, possible in the actual world); for Leibniz will surely hold that "Something is true which is demonstrably false" is (in the actual world) demonstrably false, but it must be true in any world that is not possible in itself. The transitivity of the "possible in" relation is proved as follows. Suppose there is a world $w_{2}$ which is possible in world $w_{1}$, and a world $w_{3}$ which is possible in $w_{2}$ but not in $w_{1}$. There must be some proposition $p$ which is true in $w_{3}$ but whose falsity can be demonstrated in $w_{1}$, though not in $w_{2}$. But then there is a proposition (that $p$ is not demonstrably false) which is true in $w_{2}$ but demonstrably false in $w_{1}$; its falsity is demonstrated in $w_{1}$ by demonstrating the falsity of $p$. So $w_{2}$ is not possible in $w_{1}$, contrary to the hypothesis; and the "possible in" relation must be transitive after all. It is not symmetrical, however. For there is, as Leibniz supposes, at least one proposition $p$ which is possible, and actually true, but not demonstrably possible. A world in which it is true that $p$ is demonstrably false will therefore be possible in the actual world, but the actual world will not be possible in such a world.

It is known that a "possible in" relation that is reflexive and transitive but not symmetrical is the principal feature that a system of possible worlds should have if it is to provide a semantics for S4 but not for S5. ${ }^{61}$ Thus the possible worlds semantics based on the demonstrability conception of possible worlds seems to fit the modal logic suggested by the demonstrability conception of necessity.

But does Leibniz hold this conception of possible worlds? Certainly he does not work out an S4 semantics; he does not even raise the question of a "possible in" relation among possible worlds. The crucial question is whether he 
understands "possible" in "possible world" in terms of demonstrability and indemonstrability.

He says something that implies that he does:

There are as many possible worlds as there are series of things that can be thought up which do not imply a contradiction. This thesis is identical with me, for I call possible that which does not imply a contradiction, and so in this sense it cannot be refuted. (Gr 390 [March, 1698])

I assume that "does not imply a contradiction" expresses a proof-theoretical notion here, as it usually does in Leibniz. On this interpretation Leibniz here lets a consistent, univocal use of modal terms carry the proof-theoretical or demonstrability conception of possibility into his conception of possible worlds.

On the other hand, the demonstrability conception of possible worlds has some strikingly un-Leibnizian consequences. (1) A possible individual will in general exist in more than one possible world. Leibniz holds that many of the properties contained in an individual's complete concept cannot be demonstrated from the concept. Worlds in which the individual lacks various of those properties will therefore not be demonstrably inconsistent. (2) Each actual individual will be compossible with individuals of almost every possible sort, in the sense of coexisting in some possible world with an individual of that sort. For the coexistence of a certain actual individual with any possible sort of individual will rarely if ever be demonstrably inconsistent. (3) There will be possible worlds in which different worlds will be the best possible; for the bestness of this world is not demonstrable. (4) There will be possible worlds that have (with one exception) all the perfections that the actual world (considered as possible) has, and more. There will be, for example, a world as good as the actual world in other respects, from which the horrors of the Thirty Years War are absent. Leibniz surely did not think it could be demonstrated that the world would be less perfect without the Thirty Years War. The exception, the perfection that the actual world has but those worlds lack, is conceptual consistency, as we may call the property of not involving, not even indemonstrably, a contradiction.

Leibniz never accepts these consequences. Indeed he explicitly rejects the idea of an individual existing in more than one possible world (DM 30, T 414). And for certain crucial purposes in his theory of creation he needs modalities quite different from those that are generated by the demonstrability conception of necessity. His explanation of why God did not create Judas (precisely and individually Judas) without his treason is that even God couldn't do that. Similarly he must claim that God couldn't have created a world as good as the actual world in other respects but lacking the horrors of the Thirty Years War. These "couldn't"s cannot be explained in terms of demonstrability. And Leibniz certainly does not mean that God was prevented by His goodness 
from choosing these worlds, having judged that Judas's treason and the horrors of the Thirty Years War are better than conceptual inconsistency. Rather it is not within God's power to create such worlds, because they are not possible in their own nature.

The claim that two possible substances are compossible, likewise, is surely not just the claim that they are not demonstrably incompatible, in spite of that fact that Leibniz defined "compossible" as "that which with another does not imply a contradiction" (Gr 325). For it is lack of compossibility that keeps additional excellent substances from existing in the actual world (G III,572f., C 534). But the addition of such substances is surely not demonstrably inconsistent with the concepts of actual things.

One may be tempted to accuse Leibniz of cheating in his theodicy by using modal terms equivocally. There is a sense in which God couldn't have created a better world than He did (it is conceptually false that there is such a world). But in that sense $\mathrm{He}$ also couldn't have done anything different at all (it is conceptually false that $\mathrm{He}$ does anything different). There is also a sense in which $\mathrm{He}$ could have done something different (it is not demonstrable that $\mathrm{He}$ does not, say, omit to create giraffes). But in that sense He could also have made something better than this world (it is not demonstrable that no possible alternative is better).

There is yet another sense of "could" and "couldn't" available to Leibniz, however, in which he can say, without equivocation, both of the things he wants to say. God could have done something different, in the sense that only His goodness keeps Him from doing so. But He couldn't have created a better world than this, in the sense that it is not only His goodness that keeps a better alternative from being possible. We could systematize these modalities (although Leibniz did not) by using "It is possible that $p$ " to mean roughly that if it were not a conceptual truth that God is perfectly good, it would not be a conceptual falsehood that $p .^{62}$

Leibniz's chief use of the imagery of possible worlds is at those points in his theory of creation that require this last sort of modality. "There are several possible Universes, each collection of compossibles making one of them" (G III,573). The possible worlds are the alternatives among which God chooses, and among which only His goodness keeps Him from choosing otherwise than He does. There must not be among them a world in which Judas exists but is not a traitor, or which is as good in other ways as the actual world but lacks the horrors of the Thirty Years War. The conception of a possible world that is implied by this use of the imagery, and which must therefore be reckoned Leibniz's principal conception, is not that of a world that is not demonstrably inconsistent. It is rather that of a world whose basic concept does not involve (demonstrably or otherwise) a contradiction or conceptual falsehood, a world whose basic concept is conceptually consistent. ${ }^{63}$ 
If we admit to the basic concepts of worlds information about everything except God's goodness and His choice among worlds (see section 1.2 above), this conception of possible worlds probably yields a satisfactory semantics for "It is possible that $p$ " interpreted as meaning that if it were not a conceptual truth that God is perfectly good, it would not be a conceptual falsehood that $p$. But although it would be helpful in explaining his theory of creation, Leibniz does not really develop this interpretation, and does not usually use "it is possible that" in this sense. His main conception of possibility is the proof-theoretical one that can be analyzed in terms of indemonstrability of falsehood. Thus Leibniz's main conception of possible worlds does not provide a possible worlds semantics for his main conception of possibility. If we put the two main conceptions together, we get the result that there are propositions which are possible but are not true in any possible world. "Judas exists without betraying Jesus" is such a proposition.

I do not mean to suggest that Leibniz was fully aware of the diversity of sorts of modality at work in his philosophy. Had he been conscious of it he would presumably have articulated the relevant distinctions more clearly, and avoided some apparent inconsistencies. He might also have explored the relations between the different sorts of modality and the notion of a possible world. But he did not, and it is quite misleading to think of him as a grandfather of possible worlds semantics, given the bad fit between his principal conception of possible worlds and his principal modal concepts.

\section{Epilogue: On Leibniz's Sincerity}

On no point has more suspicion of a cleavage between a public and a private Leibnizian philosophy arisen than on the problem of contingency. Leibniz's sincerity in the Theodicy has often been impugned, and often defended. It is partly but not entirely vindicated by the results of the present investigation.

It is emphatically clear in the Theodicy, as in the rest of his work, that Leibniz is a compatibilist and a determinist. The solution of the problem of contingency that is most clearly developed in the Theodicy, that non-actual things are possible in themselves even if they are not possible in relation to God's will, is one that Leibniz also held, and never abandoned, in his private papers from 1673 on. It is a solution that imposes a minimum of qualification on the necessity of all things.

The infinite analysis theory of contingency is partly stated in the Theodicy, in $\S 14$ of the Remarks on King:

For one may say in a way that these two principles [of contradiction and sufficient reason] are contained in the definition of True and False. Nevertheless, when in making the analysis of the truth that has been proposed one sees it depending on truths whose contrary implies a contradiction, one may say that it is absolutely necessary. But when in pushing the analysis as far as one pleases one is never able to arrive at such elements of given truth, one must say that it is contingent. (G VI,414) 
Here, as in a letter to Louis Bourguet in 1715 (G III,582), Leibniz says that necessary truths receive a finite analysis and contingent truths do not, but without stating that this is what contingency consists in, or that the concept of the predicate is contained in the concept of the subject even in contingent truths.

We have seen that the view that "God chooses what is best" is contingent, about which Leibniz was very hesitant in his private papers, seems to occur in one or two passages of the Theodicy. This might be due to some development in his thought, but no such explanation is plausible for the Theodicy's striking omission of any mention of the view that it is contingent that this world is the best. The latter view was well worked out, affirmed, and never rejected in Leibniz's private papers; and it is plausibly inferred from his infinite analysis theory of contingency, which he clearly continued to believe when he wrote the Theodicy.

Moreover, the frequent and unelucidated use that the book makes of the terms "moral necessity," "hypothetical necessity," and "incline without necessitating" leaves the reader with a less necessitarian impression of Leibniz's thought than these terms would leave if they were accompanied by the explanations of their meaning that are presented or suggested by his less public writings. One is not reassured about Leibniz's sincerity when one reads, in a letter from Leibniz to Des Bosses discussing the use of "moral necessity" in the Theodicy, the comment, "And in general I should prefer the words to be interpreted in such a way that nothing bad-sounding follows" (G II,419).

The lack of candor in the Theodicy is evident; the motives for it, whether pedagogical or self-protective, are not. It is interesting that Leibniz had written once, probably during the years 1675-1677,

Metaphysics should be written with accurate definitions and demonstrations, but nothing should be demonstrated in it that conflicts too much with received opinions. Thus this metaphysics will be able to be received. If it is once approved, then afterwards, if any examine it more profoundly, they will deduce that the consequences are necessary. ${ }^{64}$

One of the difficulties in the Theodicy, however, is that so many of Leibniz's "accurate definitions" are omitted that one must turn to other works to find the material necessary for a profounder examination. ${ }^{65}$

\section{NOTES}

1. Bertrand Russell, A Critical Exposition of the Philosophy of Leibniz, second edition (London: George Allen \& Unwin, 1937), p. 27. The views discussed here belong to the first edition, however, and were retracted in the Preface to the second edition.

2. E. M. Curley, "Recent Work on 17th Century Continental Philosophy," American Philosophical Quarterly 11 (1974): 242. 
3. The works of Leibniz are cited by the following abbreviations: $A=$ Leibniz, Sämtliche Schriften und Briefe, Academy edition (Darmstadt and Berlin, 1923-), cited by series, volume, and page. B = Die Leibniz-Handschriften der Königlichen Öfentlichen Bibliothek zu Hannover, ed. by Eduard Bodeman (Hannover and Leipzig, 1895). C = Opuscules et fragments inédits de Leibniz, ed. by Louis Couturat (Paris, 1903). Conf = Leibniz, Confessio Philosophi, ed., trans. (into German), with commentary, by Otto Saame (Frankfurt, 1967). DM = Discourse on Metaphysics, cited by section number. Dutens = Leibniz, Opera omnia, ed. by L. Dutens (Geneva, 1768), cited by volume, part, and page. FC = Nouvelles lettres et opuscules inédits de Leibniz, ed. by Foucher de Careil (Paris, 1857). G = Die philosophischen Schriften von Gottfried Wilhelm Leibniz, ed. by C. I. Gerhardt (Berlin, 1875-1890), cited by volume and page. Gr = Leibniz, Textes inédits, ed. by Gaston Grua (Paris, 1948). L = Leibniz, Philosophical Papers and Letters, trans. and ed. by Leroy E. Loemker, second edition (Dordrecht and Boston, 1969). $\mathrm{L}-\mathrm{A}=$ The Leibniz-Arnauld Correspondence, ed. and trans. by H. T. Mason (Manchester, 1967). $\mathrm{NE}=$ New Essays Concerning Human Understanding, cited by book, chapter, and section. $\mathrm{P}=$ Leibniz: Logical Papers, trans. and ed. by G. H. R. Parkinson (Oxford: Clarendon Press, 1966). $\mathrm{SG}=$ From Descartes to Kant, ed. by T. V. Smith and Marjorie Grene (Chicago, 1940). T = Theodicy, cited by the main series of section numbers, unless otherwise noted. To Clarke = Leibniz's side of the Leibniz-Clarke correspondence, cited by letter and paragraph number. $\mathrm{W}=$ Leibniz Selections, ed. by Philip P. Wiener (New York, 1951).

All works are cited by page number unless otherwise noted above. Entries separated by a slash refer to the original and an English translation of the same passage. I take responsibility for the translation of all quotations, although I have made some use of existing English versions.

For the dating of Leibniz's works I follow, where available, the estimates given by Heinrich Schepers, "Zum Problem der Kontingenz bei Leibniz," in Collegium Philosophicum (Basel and Stuttgart, 1965), pp. 326-350, on the basis of the then current thinking of the staff of the Academy edition. Otherwise the dates used here are those given in the editions.

4. All quotations in this section are from this letter, unless otherwise indicated.

5. Both dates are allowed, though perhaps the earlier is favored, in the Academy edition (A VI,i,537 and ii,579). But Willy Kabitz, the principal editor, seems to have assumed the later date in his previous work, Die Philosophie des jungen Leibniz (Heidelberg: Carl Winters Universitätsbuchhandlung, 1909), pp. 121-126.

6. Here Grua inadvertently omits the clause, "etsi eius coexistentia cum Deo aliquo modo dici possit implicare contradictionem."

7. Leibniz does not spell out such a distinction as this. Does he mean the basic or the complete concept of a possible world when he says, "this universe has a certain principal or primitive concept, of which particular events are only consequences" (G II, 41/L-A 44)?

8. This suggests a conception of possible worlds as less complete than they are normally conceived to be today. A similarly restricted conception persisted in post-Leibnizian German philosophy. Thus "the world" is defined by Wolff as a connected "series of changeable things," and by Crusius as "the whole aggregate of all finite things" (Christian Wolff, Vernünftige Gedanken von Gott, der Welt, und der Seele des Menschen, 9te Auflage [Halle, 1743], §544; and Christian August Crusius, Entwurf der nothwendigen Vernunft-Wahrheiten, 2te, vermehrte Auflage [Leipzig, 1753; reproduced Darmstadt: Wissenschaftliche Buchgesellschaft, 1963], $\S 204)$.

9. E. M. Curley, "Recent Work on 17th Century Continental Philosophy," p. 243. Substantially the same objection was raised by a "Roman Catholic Theologian" whom Des Bosses consulted and quoted in a note to $\$ 201$ in his Latin translation of the Theodicy (Dutens I,273).

10. I use ordinary quotation marks in place of corner quotes, since the latter are not universally understood. 
11. I owe this information, and the phrase "first Theodicy," to Saame's introduction, Conf $14,16,22$.

12. Here I translate Saame's text, minus Leibniz's later additions.

13. Leibniz, Leibnitiana: Elementa philosophiae arcanae de summa rerum, ed. I. Jagodinsky (Kazan, 1913), p. 8, quoted by Schepers, "Zum Problem der Kontingenz," p. 355, n. 24. The previous quotation is from the same page of Jagodinsky, quoted by Saame in Conf 167, n. 107. Both quotations are dated December 1675.

14. Here I translate Saame's full text, italicizing Leibniz's principal additions.

15. Here the emphasized words were underlined by Leibniz.

16. On Steno's dealings with Leibniz, see Saame, Conf 20-23.

17. The two passages quoted here were called to my attention by David Blumenfeld, who also pointed out to me the problem that they cause for my interpretation.

18. Since first writing this section I have discovered that Margaret Wilson has also remarked on this respect in which Leibniz's determinism is not Spinozistic, in her interesting paper, "Leibniz's Dynamics and Contingency in Nature," in Peter Machamer and Robert Turnbull, eds., Motion and Time. Space and Matter (Ohio State University Press, 1976), p. 285.

19. Leibniz used the concept of moral necessity much earlier, but had applied it to God's choice of the best only since 1707, according to Gaston Grua, Jurisprudence universelle et théodicee selon Leibniz (Paris: Presses Universitaires de France, 1953) (Cited as Jurisprudence hereafter), p. 235.

20. Leibniz first wrote "God's general decision is necessary"-then changed it, producing a sentence that is quite awkward in the original.

21. Schepers's date; Grua suggested 1686. The paper belongs to a period when Leibniz was in comfortable possession of the infinite analysis theory of contingency. Grua is responsible for the title, "On Contingency." In my translation I omit the many phrases crossed out by Leibniz.

22. "Verite." Grua, by mistake, has "suite." Grua has also inserted quotation marks in the text of this passage.

23. December 1705, dated 1706. See Elisabeth Labrousse, Pierre Bayle, vol. I (The Hague: Martinus Nijhoff, 1963), p. 259, n. 88. Leibniz had seen the volume by February 1706 (G III,143).

24. Nicholas Rescher, The Philosophy of Leibniz (Englewood Cliffs: Prentice-Hall, 1967), pp. 69 f.

25. E. M. Curley, "The Root of Contingency," in Harry Frankfurt, ed., Leibniz: A Collection of Critical Essays (Garden City, N.Y.: Doubleday Anchor Books, 1972), p. 94.

26. Rescher, Philosophy of Leibniz, pp. $69 \mathrm{f}$.

27. As Lovejoy points out in this connection (Arthur O. Lovejoy, The Great Chain of Being [Cambridge, Mass.: Harvard University Press, 1936], p. 173).

28. Grua has "Et hoc arcano" where he should have "Et hic arcanum."

29. "Etsi." Grua has "et."

30. FC's " $a b$ " is a misreading of "atque."

31. Alfred Tarski, "Einige Betrachtungen über die Begriffe der $\omega$-Widerspruchsfreiheit und der $\omega$-Vollständigkeit," Monatshefte für Mathematik und Physik 40 (1933): 97-112.

32. Louis Couturat, "On Leibniz's Metaphysics," trans. in Frankfurt, ed., Leibniz, p. 31; Rescher, Philosophy of Leibniz, pp. 38f.; William E. Abraham, "Complete Concepts and Leibniz's Distinction between Necessary and Contingent Propositions," Studia Leibnitiana 1 (1969): 278; C. D. Broad, Leibniz: An Introduction (Cambridge University Press, 1975), p. 35; cf. Curley, "The Root of Contingency," p. 94. 
33. Cf. Ian Hacking, "Infinite Analysis," Studia Leibnitiana 4 (1974): 127 f.

34. Lovejoy, Great Chain of Being, p. 175. Cf. Frederick Copleston, S.J., A History of Philosophy, vol. IV (Garden City, N.Y.: Doubleday Image Books, 1963), p. 286.

35. Bertrand Russell, "Recent Work on the Philosophy of Leibniz," Mind 12 (1903), reprinted in Frankfurt, ed., Leibniz, p. 378, n. 8.

36. Rescher, Philosophy of Leibniz, p. 44, n. 24.

37. In DM 13 and $\S \S 131$ and perhaps 74 of Generales Inquisitiones (C $388,376 \mathrm{f}$ ), Leibniz seems to speak of a "demonstration" of contingent truths which is beyond the powers of finite minds to accomplish. And in an early text (G VII,194) he speaks of all truths as "demonstrable." This may be due either to carelessness or to some variation in his terminology during a formative period of his thought. Usually (e.g., C If.) he is careful not to say contingent truths have "demonstrations" though they have "proofs" a priori that are known to God.

38. Curley, "The Root of Contingency," p. 94.

39. Russell, "Recent Work on the Philosophy of Leibniz," p. 374, n. 5; cf. Russell, A Critical Exposition of the Philosophy of Leibniz, p. 26.

40. Broad, Leibniz: An Introduction, p. 36; Curley, "The Root of Contingency," pp. $92 \mathrm{f}$.

41. Fabrizio Mondadori, in "Leibniz and the Doctrine of Inter-World Identity," Studia Leibnitiana 7 (1975): $32 \mathrm{f}$., takes it that what is not necessary here is the actualization of the individual; but that does not adequately explain why Leibniz should call the connection contingent.

42. See p. 5 .

43. I am indebted to William Irvine for this name for it.

44. Cf. Broad, Leibniz: An Introduction, p. 27.

45. Lovejoy, Great Chain of Being, p. 174.

46. Leibniz seems strangely to overlook this point in a letter to Jaquelot of 1704 , where he explicitly links the notion of inclining with things being too complex for us to understand them. For he says that "future things are contained in the soul even less than in God, because they are in the soul distinctly only in an inclining and confused way, and not explicitly and perfectly as in the Divine ideas" (G III,472). This linkage of themes is revealing, but Leibniz has the shoe on the wrong foot in this text. For he thinks that God too is only inclined, not necessitated by reasons (T 230), although His perceptions are in no way confused. It is not confusion, therefore, but the infinity of factors which in our finite minds gives rise to confusion, that is of the essence of inclination.

47. Leibniz muddied the waters a little by adding "or identical" to the claim that the first of these is "a first proposition"; but the context makes clear that what he really wanted to say is that it is like an identical proposition in being a truth but undemonstrable.

48. This paper (quoted in section 1.2 above) is also an important source for the view that non-actual things remain possible in their own natures even if they are not possible in respect to the divine will. It might be quibbled whether in the quoted passage demonstrability is denied only de re, with respect to that which is most perfect; but I think that would be an unnatural reading of the text.

49. The same set of notes, however, expresses the view that it is demonstrable that God cannot do evils, which I will discuss below. The reference to Aquinas is given as Summa contra gentiles, I,lxxxii ff.; it should have been given as I, 1xxx ff.

50. Grua, Jurisprudence, p. 307.

51. Rescher, Philosophy of Leibniz, p. 45; Curley, "The Root of Contingency," p. 95. 
52. Robert Merrihew Adams, "Must God Create the Best?" The Philosophical Review 81 (1972): 317-332.

53. Quoted by Grua, Jurisprudence, pp. 212f., from Mittheilungen aus Leibnizens ungedruckten Schriften, ed. by G. Mollat (Leipzig, 1883), p. 48. Grua says the text is from 1701-1705. On this subject see in general pp. 198-222 of Grua's Jurisprudence.

54. Rescher, Philosophy of Leibniz, p. 39.

55. Curley, "The Root of Contingency," p. 96.

56. Rescher, Philosophy of Leibniz, p. 45.

57. I owe this reference to Abraham, "Complete Concepts," p. 278.

58. Couturat, "On Leibniz's Metaphysics," p. 28.

59. Curley, "The Root of Contingency," p. 91.

60. See Robert Merrihew Adams, "The Logical Structure of Anselm's Arguments," The Philosophical Review 80 (1971): 45f., for a brief argument on this point.

61. Saul Kripke, "Semantical Analysis of Modal Logic I: Normal Propositional Calculi," Zeitschrift für mathematische Logik und Grundlagen der Mathematik 9 (1963): 67-96.

62. I assume here that a counterfactual conditional with a conceptually false antecedent need not be vacuously true or vacuously false. I think this assumption could be justified within the framework of Leibniz's analytic theory of truth.

63. Cf. Schepers, "Zum Problem der Kontingenz," pp. $345 \mathrm{f}$.

64. In a note published by Henri Lestienne in his critical edition of Leibniz's Discours de Métaphysique, second edition, (Paris: Vrin, 1952), p. 14n.

65. My greatest debt in this essay is to the monumental scholarship of Gaston Grua's Jurisprudence universelle et theodicee selon Leibniz, whose copious textual references provide an indispensable guide for anyone exploring this subject in Leibniz. $\mathrm{I}$ am also indebted to those who have attended my classes on Leibniz at the University of Michigan and UCLA, and particularly to John Earman, for helpful discussion. When I presented the paper at the Leibniz conference at Rice University, I discovered that David Blumenfeld had arrived independently at some of the ideas I have expressed here. He does not entirely agree with me, and has persuaded me that I ought perhaps to have been more sharply critical of what I have called Leibniz's second main solution to the problem of contingency, as not really being relevant to issues about freedom, which is not a proof-theoretical concept even if contingency may be. I have found Blumenfeld's comments very helpful in revising the paper. Several improvements are due to Heinrich Schepers, who read and commented on a draft of the paper. I am particularly indebted to him and the other members of the staff of the Leibniz-Forschungsstelle of the University of Münster for advice and for access to transcriptions and microfilms of Leibniz manuscripts, which have enabled me to correct the texts of Grua and Foucher de Careil in a few places, which I have indicated in the notes. The responsibility, of course, for any textual error that may have been introduced or overlooked here is mine. 